Historic, Archive Document

Do not assume content reflects current scientific knowledge, policies, or practices. 



\section{WERNICH

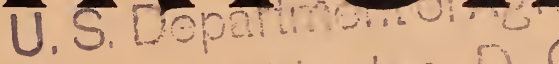 SEED CO.}

Bullbs $_{\text {For }}^{\text {and }} S_{e_{e d s}}$

Fall Planting

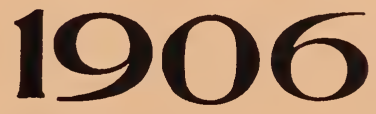

27=29 Juneau Ave.

G14 River St.

MILWAUKEE on WIS. L 


\section{Bulbs for Fa11 Planting.}

Bulbs Ready for Shipment on or About September Io.

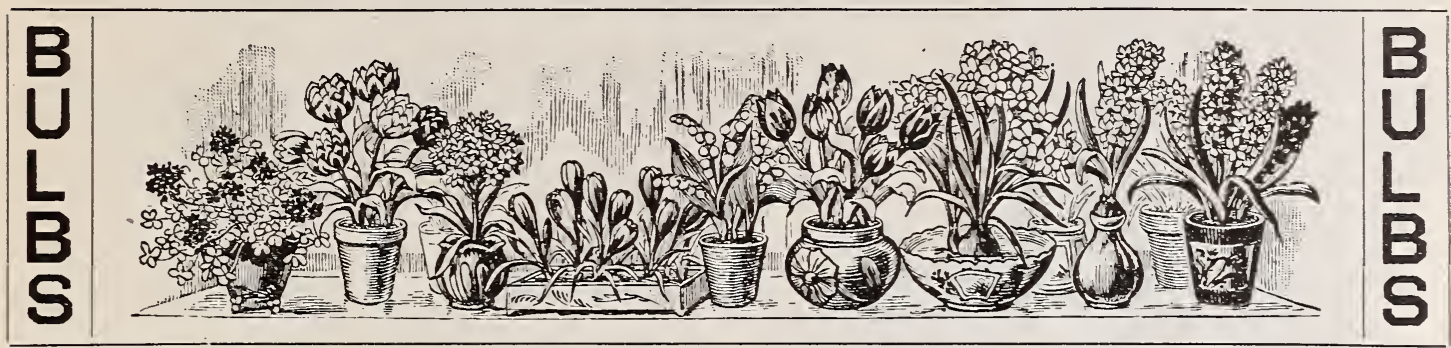

Bulbous Plants are among the most showy and useful of our garden farorites are easily managed and are sure to bloom. The outdoor display may be fairly said to commence with March, when the garden is growing bright with Snowdrops, Scillas, Chionodoxas, Crocuses, Dalfodils, etc., and during April and well into May the flower-beds are brilliant and charming with a wealth of lorely Hyacinths, Tulips, Anemones, Narcissus, etc., which make up a display of floral beauty rarely equaled. As winter-blooming plants they hold an important place, as there is no period of the year during which flowers a :e so lighly appreciated, and certainly no class of flowering plants affords more pleasure. It is no difficult matter, by early planting and forcing a few Tulips, Roman and other Hyacinths, Paper-white Narcissus, etc., to hare them in bloom by New Year's das, while a few successive plantings of these and other choice sorts will ensure a beautiful display throughout the dull winter months.

\section{CULTURE OF HARDY BULBS.}

\section{INDOOR CULTURE.}

Potting.-The bulbs should be planted in pots as soon as received. The soil should be rich and well mixed with at least one-third of old well-rotted manure; fill the pot nearly full of soil, place the bulb in, then fill in with pot nearly full of soil, place the bulb in, then the within half an inch of the top of the pot.

After Potting.-To get the best results in flowering, the pots must be filled with roots before the top starts to grow, and to do this they must be plunged in some cool place. The most satisfactory method is to plunge the pot in the earth an inch or more below the
surface, right out in the garden. Select a sheltered position, high enough so that water from rains will not settle and remain stagnant around the pots. When the weather gets cold enough to freeze the ground, place three or four inches of leaves, straw or other refuse over the soil where the pots are plunged. Bulbs should be sufficiently rooted in about eight or ten weeks after potting to have the pots lifted and brought in the house for flowering. But to be sure that the roots have developed properly, place the hand orer the top of the pot, turn it upside down and tap the pot slightly, when the ball of earth will slip out of the pot; if the roots are plainly showing all around the earth the bulb is well rooted; place back in pot and remove to the house for flowering whenever desired. They should then be grown on in the, house in a temperature
of from sixty to sevenfy degrees, and should bloom in from six to eight weeks.

\section{OUTDOOR CULTURE.}

To secure really fine flowers outdoor planting should be done early in the fall, though generally speaking, from October to the middle of November is the most desirable time. Most bulbs succeed in any well-drained good garden soil which, however, should be dug at least eighteen inches deep. Hardy bulbs throw out their roots during the fall and winter-they usually root deeply; therefore the bulbs should be planted from three to four inches below the surface, so as to be as free as possible from the upper crust of the soil, which heaves considerably, caused by alternate freezing and thawing, thus causing bulbs planted too near the surface to break from their roots. A little sand placed below and around the bulbs permits the water to drain off in heary soils. Beds should be in a sunny position, if possible, and protected during the winter by a coating of rotted manure. The bulbs may be taken up and dried off as soon as the leaves acquire a vellow color; the beds will be vacant in time for the ordinary bedding plants. If it is found necessary to remove the bulbs immediately after flowering they should be carefully taken up, the leares and roots damaged as little as possible, and "heeled in" in some slightly shaded place until the foliage is quite withered and the bulbs thoroughly ripened, when they may be taken up, cleaned, and stored in a cold, dry shed or cellar until wanted for the next fall's planting.

\section{SUPERFINE TIIXED HYACINTHS.}

Our mixtures are unexcelled for use where an effective display is wanted in the open air, and are of such superior quality as to be entirely satisfactory to florists and others who use large quantities for forcing. They comprise the finest shades of color and must not be confounded with the cheap mixtures sometimes offered for outdoor planting.

If Sent by Mail add 10 cents Per Dozen for Postage.

Single Bulbs Mailed Free.

Each. Doz. Per 100 Single Pure Thite ...\$0 05 \$0 50 \$3 95 Single Blush White... 05 Single Red ........ 05

Single Rose ......... 05

Single Dark Blue .... 05

Single Light Blue.... 05

Single Yellow ........ 05

Single, all colors.....

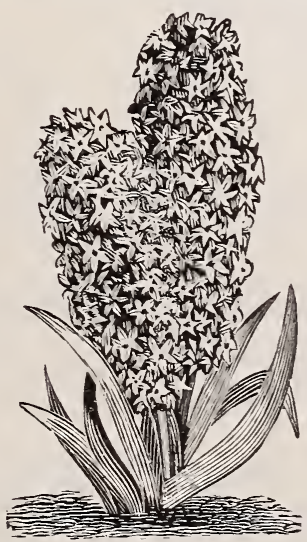

If Sent by Mail add 10 cents Per Dozen for Postage.

Single Bulbs Mailed Free.

Each. Doz. Per 100. Double Pure White...\$0 05 \$0 50 \$3 95 Double Blush White.. $05 \quad 50 \quad 395$ Double Red ......... $05 \quad 50 \quad 395$ Doulbe Rose ........ $05 \quad 50 \quad 395$

Double Dark Blue.... $05 \quad 50 \quad 395$ Double Light Blue... $05 \quad 50 \quad 395$

Double Yellow ...... $05 \quad 50 \quad 395$

Double, all colors.... ... $50 \quad 395$

6 Bulbs at Dozen rates; 25 at 100 rates. 


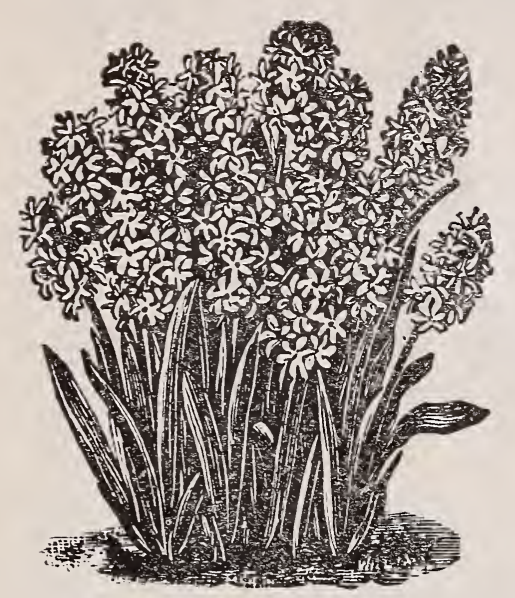

\section{Roman Hyacinths.}

If sent by mail, add $10 \mathrm{c}$ per doz. for postage. Single bulbs mailed free.

These are specially valuable for forcing and pot culture in the house, each bulb producing from two to six spikes of dainty, very fragrant flowers.

A very pretty effect with Roman Hyacinths is obtained by planting 10 to 12 bulbs in an earthen pan 8 or 9 inches across. Several of these pans can be filled and put away to root in the usual manner, and by bringing them in from time to time a beautiful display can be enjoyed for weeks.

\begin{tabular}{|c|c|c|c|}
\hline Rose Ror & $\begin{array}{l}\text { Each. } \\
. \$ 0.04\end{array}$ & $\begin{array}{c}\text { Dozen. } \\
\$ 0.40\end{array}$ & $\begin{array}{r}\text { Hundred. } \\
\$ 3.00\end{array}$ \\
\hline hite Ror &.$\quad .04$ & .50 & 3.75 \\
\hline Ron & .04 & .40 & 3.00 \\
\hline ellow Roman & .10 & 1.00 & 7.00 \\
\hline
\end{tabular}

Six Bulbs at Dozen Rates and 25 at 100 Rates.

\section{Grape, Musk and Feathered Hyacinths.}

Are very pretty for permanent beds and edgings and partially shady situations. Plant in groups of one dozen or more and they will soon spread. Being perfectly hardy they require no care after once planted. Also pretty when grown six in a pot for house culture.

Grape Hyacinths. Produce flowering spikes about 6 inches high, resembling a bunch of grapes. 2 bulbs for 5 cents; 20 cts. per dozen; $\$ 1.00$ per 100 , postpaid.
Musk Hyacinths. Of dwarf growth, purple in color, and emitting a strong musky odor when in flower. Each 10 cents; $\$ 1.00$ per dozen, postpaid.

Feathered Hyacinths. Forms pretty spikes of flow. ers resembling a feathery plume, very effective for outdoor culture. 3 bulbs for 10 cts.; per dozen 25 cts.; per $100 \$ 1.75$, free by mail.

\section{TULIPS.}

If by Mail Add 5 Cents Per Dozen, and 40 Cents Per 100. Single Bulbs Mailed Free.

A universal favorite. Easy of cultivation. For a handsome display in the garden in the early spring, before even daring to plant summer flowering plants, there is no plant so effective, nor none so reliable as the Tulip. Can also be grown in pots for house culture, and when so planted are incomparable. Culture about the same as the Hyacinth for Spring blooming. All the varieties listed below bloom at about the same time and are of equal height, making it an easy matter for the purchaser to select from.

\section{SINGLE TULIPS.}

Artus, Pure Scarlet

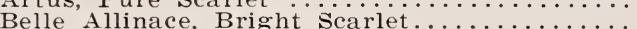

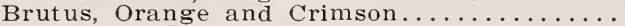

Chryselora, Large Yellow

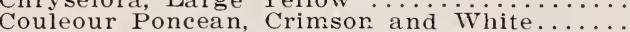

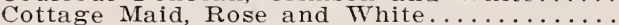

Jagt van Delft, White.

Kaiser Kroon, Red and Yellow.

La Reine, White, Rose Shaded.

Yellow Prince, Golden Yellow.

\section{DOUBLE TULIPS.}

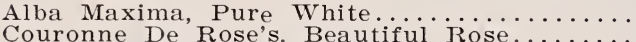

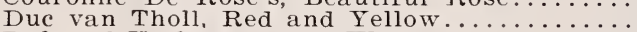

Duke of York, Red and White.

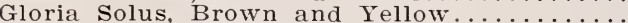

La Candeur, Pure White.

Rex Rubrorum, Scarlet

Rosinee, Light Rose

Tournesoll, Red and Yellow

Tournesoll, Pure Yellow

Each.
$\$ 0.03$
.04
.03
.04
.03
.04
.03
.04
.03
.04

$\begin{array}{cr}\text { Dozen. } & \text { Per } 100 . \\ \$ 0.30 & \$ 1.35 \\ .35 & 2.60 \\ .30 & 1.35 \\ .30 & 1.65 \\ .30 & 1.35 \\ .30 & 1.65 \\ .30 & 1.35 \\ .30 & 1.65 \\ .30 & 1.35 \\ .35 & 1.85\end{array}$

$\begin{array}{lll}.04 & .35 & 2.50 \\ .06 & .70 & 5.10 \\ .03 & .25 & 1.25 \\ .03 & .25 & 1.35 \\ .03 & .30 & 1.60 \\ .03 & .30 & 1.60 \\ .04 & .35 & 1.85 \\ .03 & .30 & 1.60 \\ .04 & .35 & 1.85 \\ .05 & .50 & 3.60\end{array}$

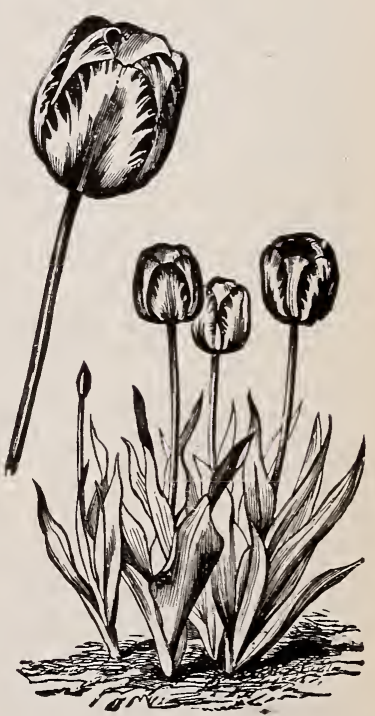

MIXED TULIPS.

SINGLE.

No, 1, Extra Fine Varieties.... Dozen. Per 100.

No. 2, Fine Varieties ............ $\$ 0.25 \quad \$ 1.25$
DOUBLE.

Dozen. Per 100

No. 1, Extra Fine Variety........\$0.30 \$1.50

No. 2, Fine Varieties ............. $.25 \quad \$ 1.25$

\section{PARROT OR DRAGON TULIPS.}

These belong to the late or May-flowering Tulips, and have immense attractive flowers of singular and picturesque forms and brilliant and varied colors. The petal $s$ are curiously fringed or cut and the form of the especially before it opens, resembles the neck of a par rot. Each, 3c; Doz., 25c; Per 100, $\$ 1.25$. 


\section{NARCISSUS-DAFFODILS.}

"The Flower of the Poets." Appearing, as they do, just after bleak winter, they turn our gardens, la $m$ ns and woodland walks into gorgeous masses of gold and silver, with a fragrance that is enchanting. They ar equally valuable for growing in pots, for winter flowering and are prized for pot culture, flowering in the house with the Hracinth, and should be cultirated in the same way-3 roots, at least, in a 4 or 5 inch pot. 'The cut flowers of Daffodils are much in demand for bouquets and vases, and some of the varieties are forced in immence quantities by florists for cut flowers in winter. Narcissus are of the easiest culture, and all, excepting the Polvanthus rarieties, are perfectly hards, though the latter live through the severe winters-if well protectedand produce larger and more abundant flowers than when grown in the green-house.

\section{SINGLE VARIETIES.}

If by mail add $10 \mathrm{c}$ prrdoz. Single bulbs mailed free.

Biflorus. Thite Each. Doz. 100.

Biflorus. White with rellow cup...\$0.03 $\$ 0.25 \quad \$ 1.25$ Poeticus. (I'heasant's Eye). Snow white with citron cup............... . .02 $15 \quad$.75 Princeps. Large sellow trumpet with sulphurs perianth ......... $04 \quad .30 \quad 1.50$ Psendo. (Lent Lils). Yellow trumpet $\ldots \ldots \ldots \ldots \ldots \ldots \ldots \ldots \ldots \ldots \ldots . .03 \quad .30 \quad 2.00$ Trumpet Major. Large, rellow...

\section{DOUBLE VARIETIES.}

Alious Plenus odoratus. Pure Incomparable (Butter and Eggs). Sulphur vellow, sweet scented 03 $\begin{array}{rlll}\text { Ornghur yellow, Sweet scented... } & .03 & .25 & 1.50 \\ \end{array}$ sulphur Phoenix. Yellow and white ................... The finest of all sellow Daffodils, used extensirely for forcing as well as for bedding out doors $\ldots \ldots \ldots \ldots \ldots \ldots \ldots \ldots \ldots \ldots \ldots . .03 \quad .30 \quad 2.00$

\section{MIXED VARIETIES.}

Single. Many pretty varieties.......\$0.25 $\quad \$ 100$. Double. A choice mixture ...........

\section{Polyanthus Narcissus.}

If by mail add $15 \mathrm{cts}$. per doz. Single Bulbs mailed free.

The Polyanthus varieties are much esteemed for pot culture indoors, continuing in bloom a long time. They flower very freely and all the varieties are very fragrant.

Each. Doz. 100 cup ......................\$0.04 \$0.40 \$2.50

Grand Soleil d'Or. Golden yellow. $.04 \quad .40 \quad 2.50$

Paper White Grandifiora. Flowers large and of more vigorous growth than the preceding........... $.03 \quad .30 \quad 1.75$

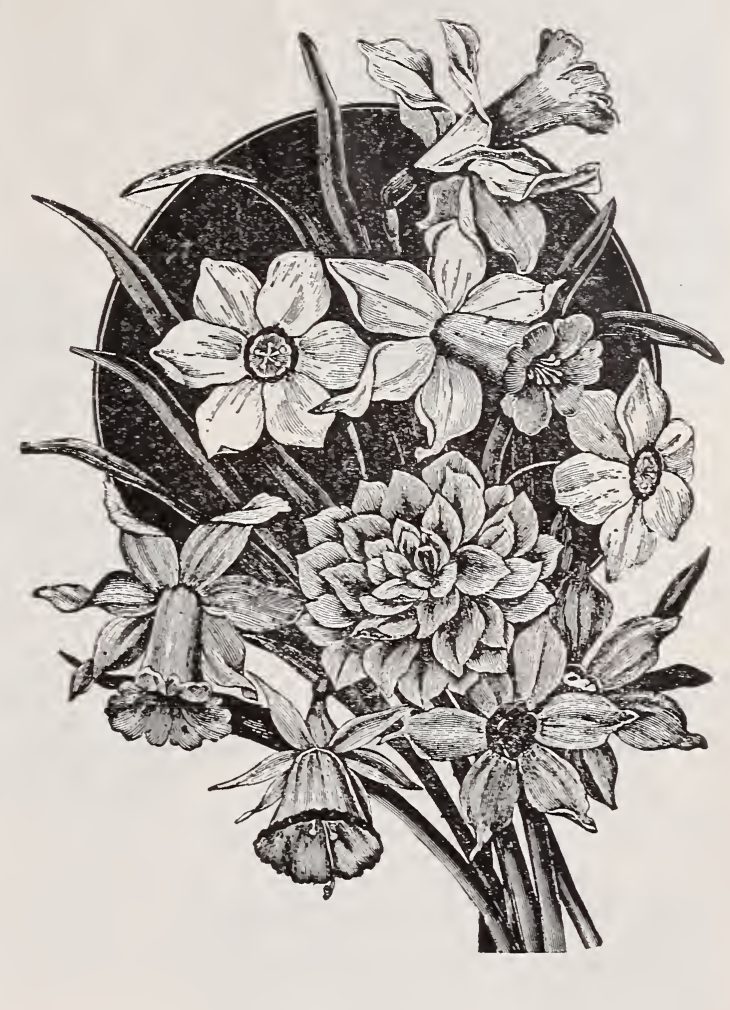

JONQUILS.

If by mail add 15 cts. per 100 .

Much prized for their charming golden and deliciously sweet scented flowers, perfectly hardy and flowering very early in the spring; they are also admirably adapted for winter forcing.

Single Jonquil. The well-known fa-

Each. Doz. 100.

vorite, delicately scented and beau-

tiful for forcing. Rich yellow

very fragrant ................\$0.02 \$0.10 \$0.75

Double Jonquil. Heads of smail

but rery donble deep golden vel-

low flowers, powerfully scented and

good for forcing ................. .03

\section{CROCUS.}

"THE HARBINGERS OF SPRING."

No Spring display surpasses that of Crocus; the broad, wavy bands of golden yellow, striped, purple or of pure white. When they expand their blossoms, in February or March, are incomparable. In lawns and pleasure parks, planted in the grass, the Crocus is extremely effective. They are easily planted indiscriminately in the turf with the aid of a dibber-after fall rains have made the sod moist. After Large White, Striped, Blue and Yellow, each color se parate, per dozen, $10 \mathrm{c}$, per $100,40 \mathrm{c}$, per 1,000 , $\$ 3.75$.
All Colors lixed, per dozen, $10 \mathrm{c}$, per $100,35 \mathrm{c}$, per $1,000, \$ 3.25$. 


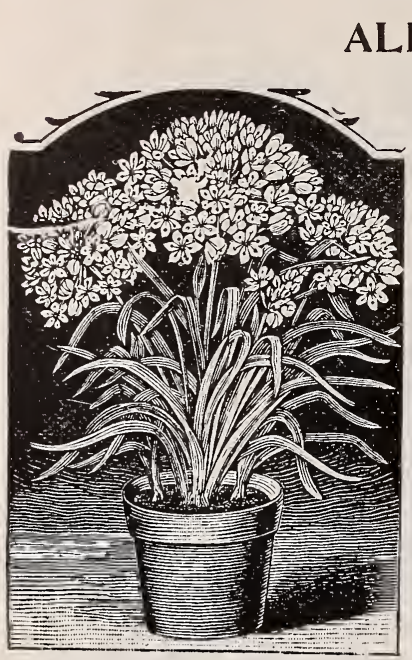

ALLIUM.

Charming hardy spring

flowering

plants.

\section{Neapolitanum- \\ Flowers white, borne in umbels; useful for cut flowers. \\ Each. Doz. 100. $\$ 0.02 \$ 0.15 \quad \$ 0.80$}

Molly.-Bright golden yellow.

Each. Doz. 100. $\$ 0.02 \$ 0.15 \quad \$ 0.65$

Azureum. - Intense blue, very showy and effective.

Each Doz 100. $\$ 0.08 \quad \$ 0.75 \quad \$ 6.00$

\section{ANEMONES.}

Highly ornamental spring and summer flowering plants, having both single and double flowers, the colors of which are vely beautiful. Anemones are also splendid for pot culture, for flowering in the house or conserratory during winter.

Sing:le.

Each. Per Doz. Per 100. $\begin{array}{llll}\text { Double........................... } & \$ 0.03 & \$ 0.15 & \$ 1.00 \\ & .25 & 1.50\end{array}$

\section{Chionodoxa, or Glory of the Snow.}

These are praised by all as the most exquisite of spring flowering plants, and when grown in quantities under shrubs the effect is strikingly beautiful. They nroduce flower spikes bearing ten to fifteen lovely Scilla-like flowers. They are perfectly hardy, and may be planted as an edging to a bed, or in clumps or masses, where they are doubly welcome, flowering early in the season with the Snowdrops, and lasting a long time in perfection. They will thrive well in any good garden soil, and n:e admirable for pot culture for winter blooming in the house and for forcing for cut flowers.

Each Doz. 100. Lucillae.-Bright blue, white center. $\$ 0.03 \quad \$ 0.20 \quad \$ 1.00$ Sardinensis.-Intense blue ….... .0 $\quad .03 \quad 1.00$

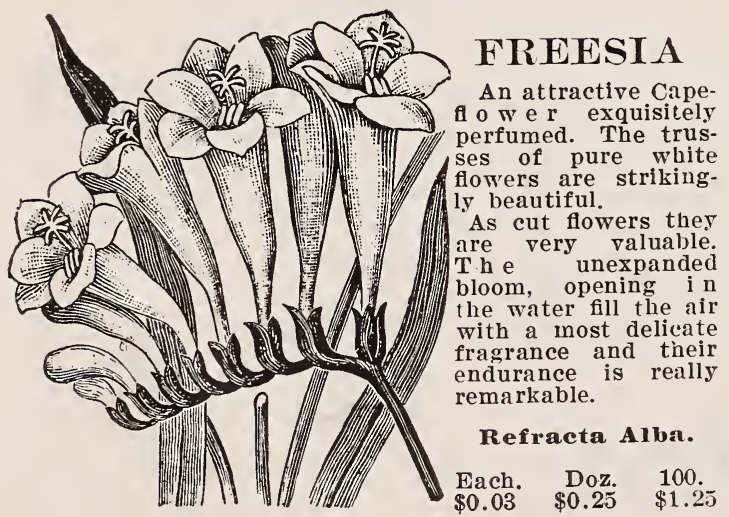

Freesia.

\section{GIANT SNOWDROPS.}

"his pretty little flower is generally the first to appear un spring, often rearing their delicate heads above a light covering of snow in early March. Suitable for pot culzure, but most effective when planted in clumps on the tawn. September and October is the best time to plant. Requires no protection over winter.

$$
\text { Each. Per Doz. Per } 100 .
$$

Pen. Per Doz. Per 100

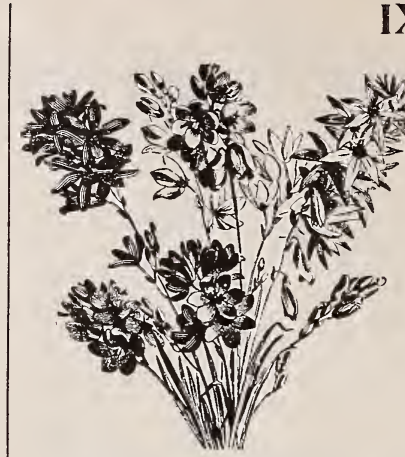

IXIAS.

The Ixia is not as generally known as it deserves. Its little star-
shaped flowers are unassuming, but very pretty and very interesting. They present almost every known color-three or four different hues appearing in almost every flower. It is best adapted for pot-culture, and for effect $\mathrm{s}$ e $\mathrm{v}$ e $\mathrm{r}$ a l bulbs should be planted in the same pot.

Mixed Varieties.

$\begin{array}{lll}\text { Each. } & \text { Doz. } & 100 . \\ \$ 0.02 & \$ 0.15 & \$ 0.85\end{array}$

\section{LEUCOJUM VERNIM OR SPRIIG SIUWFIAKE.}

These produce flowrrs like monster Snowdrops, having the delicate fragrance of the Violet. It is one of our earliest spring flowers, with white blossoms distinctly tipped green; handsome in outline and prized for bouquets. Very graceful in growth they should be grown in quantities in the borders or in clumps on the edges of shrubbery, where they are beautifully effective. They can also be slowly forced in pots for winter bloom. cts. each, per doz. 25 cts., per $100 \$ 1.50$.

\section{OXALIS.}

Charming little half-trailing or bushy plants particularly adapted for pot culture and hanging baskets. Plant 6 to 12 in a pot, and if several varieties are potted together, a very charming effect will result.

Bowei, Rosy

Each. Doz. 100.

Crimson $\ldots$... $\$ 0.03 \$ 0.25 \$ 1.75$ Cernua, D'ble

Yellow $\ldots$

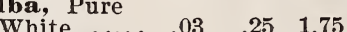

Mixed, All

Colors $\ldots . . . \quad \ldots \quad .25 \quad 1.75$

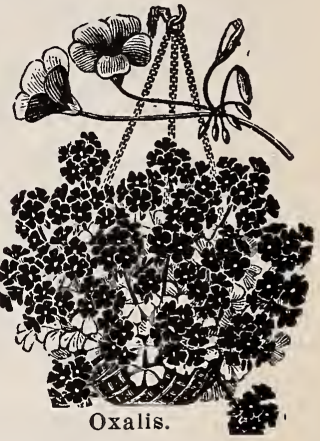

\section{ORNITHOGALUM.}

Arabicum. (Arabian Star of Bethlehem.) A beautiful variety throwing up a tall spike bearing numerous large, milk-white, star-shaped flowers with a black center, and having a distinct aromatic perfume. They are decidediy pretty and interesting when grown in the garden, but are more largely grown for greenhouses and window decoration, being of the easiest culture. 5c each, 50c per doz., $\$ 3.00$ per 100.

\section{RA YUNCULUS.}

Among the dwarf flowers these are unrivaled for lovels form and bright and attractive colors, ranging through gorgeous shades of white, crimson, yellow, purple black, many of them being beautifully marked with other shades. They flower profusely in pots in the house or if grown in frames in the spring.

Double Giant French.-Remarkable vigorous grōwers. 2 for 5c, $20 \mathrm{c}$ per doz., $\$ 1.00$ per 100 .

Double Persian.-Camelia or rose-shaped flowers. 2 for 5 c, 20c per doz., $\$ 1.00$ per 100 .

\section{SCILLA.}

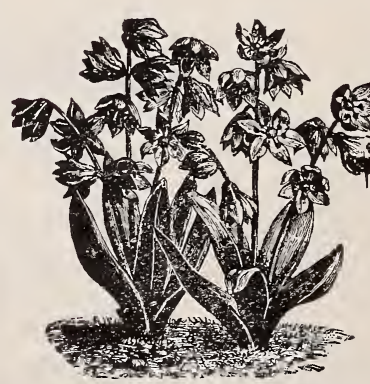

Sibirica.-(Amoena or Praecox.) One of our most beautiful, hardy spring bulbs, producing in profusion masses of exquisite fusion masses of exquisite before the snow has disappeared. If grown in masses their flowers fairly carpet the ground, and if grown with Snowdrops and Crocus, for contrast, the effect is magnificent. Grown in pots, they may be had in bloom from Christmas until April. 3 for $5 \mathrm{c}, 20 \mathrm{c}$ per doz., $\$ 1.00$ nes ino.

If by mail, add 15 cts. per 100 extra. 


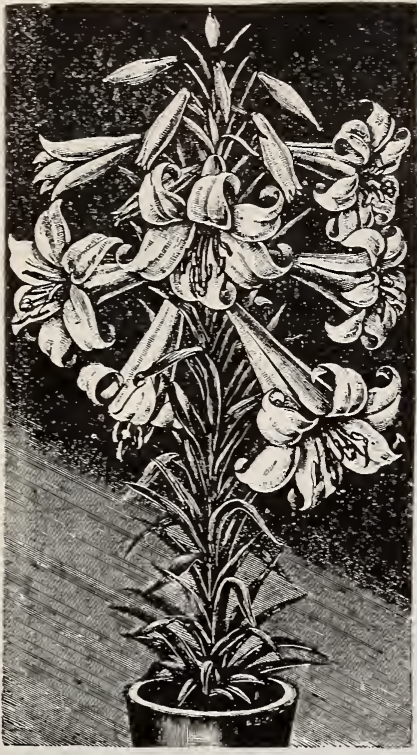

Easter Lily.

Black Calla (Arum Sanctum). The flowers grow fully a foot in height, almost coal black and green underneath. Per bulb, 15c; doz. \$1.50.

White Calla (Ethiopica). Lily of the Nile. Too well known to need description. Per bulb, 15̆c; doz., \$1.50.

Red Calla (Arum Cornutum). Flower red, spotted black, stems in both white and green, and foliage handsome. Per bulb, 15c; doz. \$1.50.

\section{FRITILLARIA.}

A group of dwarf spring flowering plants, bearing singular large pendent bell-shaped flowers of white, purple, bronze, black or yellow, most of which are striped, splashed or checkered in the most fantastic fashion; they are invaluable for pot culture, and exceedingly pretty when grown in large clumps in the border in a dry situation. Recurva. Flowers bright and red, mottled with yellow. Each 10c, per doz. $\$ 1.00$.

\section{CROIVN IMPERIALS.}

Well-kaown spring-blooming, stately, hardy border plants, with clusters of immense pendent bell-shaped flowers, surmounted with a tuft of green leaves. They are very effective and if left undisturbed for years they iorm gigantic and picturesque groups of gorgeous colors. The variegated leaved ones are especially excellent and also very effective for conservatory decoration among dwarf-growing plants.

Aurora. Red. Each, 15̃c, per doz. \$1.3.

Lutea. Yellow. Each 25c, per doz. $\$ 2.00$.

Gold Striped. A splendid variety, the rich, green foliage of which

is beautifully striped golden yellow, producing a striking effect

to the bright red flowers, which are borne in clusters. Each 25c, per doz. $\$ 2.50$

Fine Mixed Varieties. Each 15c, per doz. \$1.50.

\section{THE CHINESE SACRED OR ORIENTAL NARCISSUS.}

The "Shui Sin Far," or Water Fairy Flower, Joss Flower, or Flower of the Gods, etc., as it is called by the Celestials, is a variety of Narcissus, bearing in larish profusion chaste flowers of silvery white, with golden rellow cups. They are of exquisite beauty and entrancing perfume. It is grown by the Chinese, according to their ancient customs, to herald the advent of their new year, and as a symbol of good luck. The bulbs are grown by a method known only to themselves, whereby thes attain great size and vitality, ensuring luxuriant growth and immense spikes of flowers; in fact the incredibly short time required to bring buIbs into bloom (four to six weeks after planting) is one of the wonders of nature. "You can almost see them grow," succeeding almost everywhere and with everybody. They do well in pots of earth, but are more novel and beautiful grown in shallow bowls of water with enough of fancy pebbles to prevent them from toppling over when in bloom. A dozen bulbs started at. intervals will give a succession of flowers throughout the winter. Each 15c, $\$ 1.40$ per doz., postpaid. By express, at purchaser's expense, $10 \mathrm{c}$ earh, 3 for $25 \mathrm{c}, \$ 1.00$ per doz. Original baskets of 30 bulbs, $\$ 1.90$, by express at purchasers' expense.

All Bulbs on this Page Delivered Free (except ryere

\section{LILIES.}




\section{Flower-Bed Collections.}

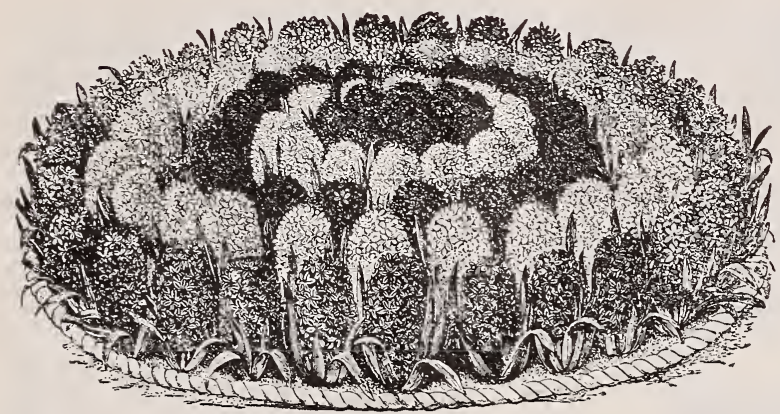

\section{Round Bed of Hyacinths.}

This Bed is $\mathbf{1 5}$ feet in circumference, or 5 feet across, composed of 5 circular rows, requiring a tota

of 100 bulbs planted 6 inches apart, viz.:

1st row (center) contains 9 Dark Blue Hyacinths.

$2 d$ row contains 14 White Hyacinths.

3d row contains 20 Red Hyacinths.

4th row contains 25 Pink Hyacinths.

5th row (outside) contains 32 Light Blue Hyacinths.

Price..$\ldots \ldots \ldots \ldots \ldots \ldots \ldots \ldots \ldots \ldots \ldots \ldots \ldots \ldots \ldots \ldots \ldots$

(Purchaser's option to change combination.)

\section{Round Bed of Single Tulips.}

5 Feet in Diameter, requiring 120 bulbs planted 5 inches apart. 3 colors. Purchaser paying transit.

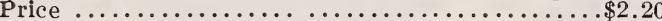

6 Feet in Diameter, requiring 170 bulbs planted inches apart. 3 colors. Purchaser paying transit.

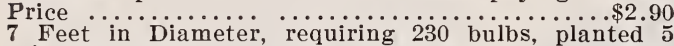
inches apart. 3 colors. Purchaser paying transit.

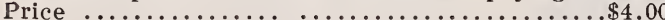

\section{Round Bed of Double Tulips.}

5 Feet in Diameter, requiring 120 bulbs planted 5 inches apart. 3 colors. Purchaser paying transit.

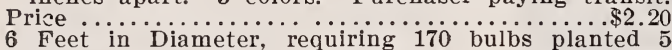
inches apart. 3 colors. Purchaser paying transit.

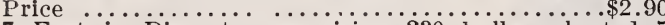
7 Feet in Diameter, requiring 230 bulbs, planted 5

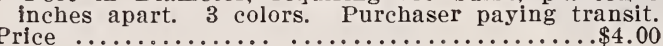
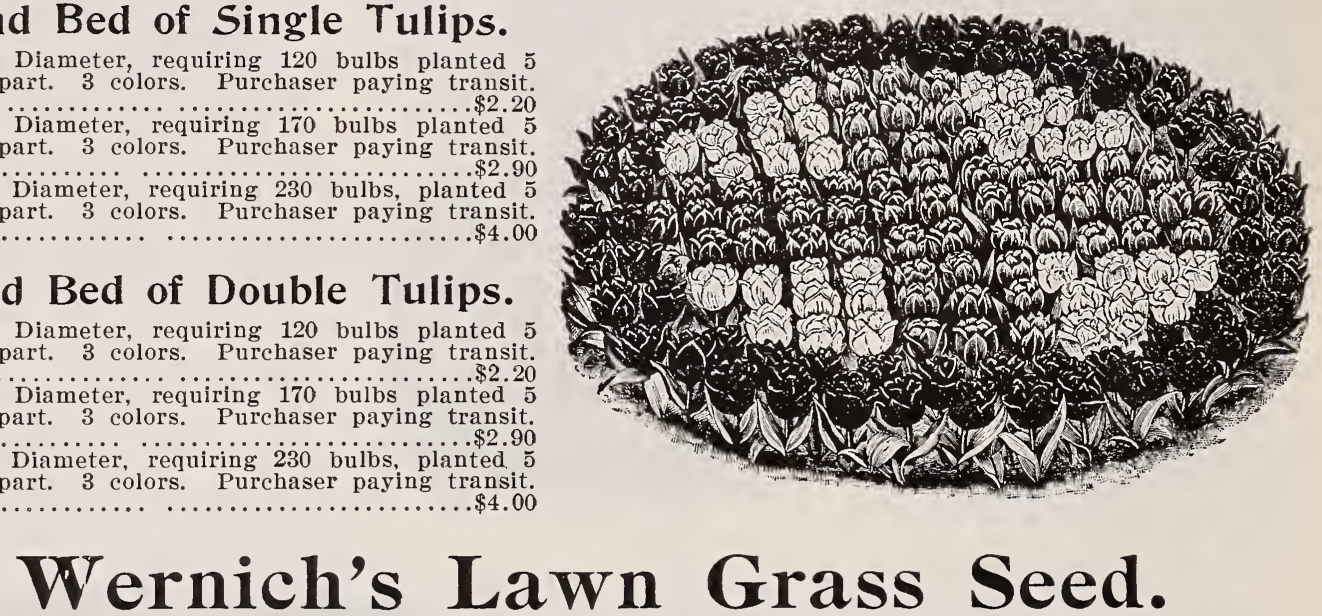

Our Lawn Grass, sown in autumn, will produce a fine luxuriant Lawn EARLY the following season.

Where other dealers' seed has failed ours proved successful.

The principal features to secure a good lawn are: First, a rich, well-drained soil; second, careful preparation of the ground, making it as fine, smooth and mellow as possible; third, a wise selection of Seeds; fourth, sowing at such a time as to give the young plant time to become. well established before being subject to very dry oi very cold weather. Seeding may be done in Spring or Fall. If done during the hot months of summer, the ground must be kept moderately moist when sowing is done. With the ground prepared well, let the sufface be gone over with a fine rake, and the seed evenly scattered, after which carefully rake or brush the seed

in and follow with a roller. SIED REQUIRED.

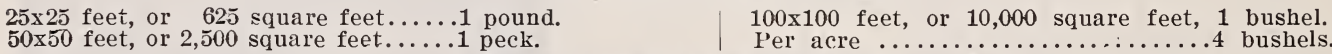

Werni-h's "Fine Mixed" Lawn Girass.

A mixture containing cheaper grades of grass seeds than our "Peerless Lake Park Mixture." Prepaid, $1 / 2$ lb. $15 \mathrm{c}, 1 \mathrm{~b} .30 \mathrm{c}$, peck 95c; not prepaid, per' $1 / 2$ lb. $10 \mathrm{c}$, per $1 \mathrm{~b}$. $20 \mathrm{c}$, per peck (31/2 lbs.) 6 כe, per bushel (14 lbs.) $\$ 2.50$, per 4 bushels $\$ 9.00$, per 100 lbs. $\$ 17.50$.

\section{Wernich's "Lake Park" Lawn Grass.}

This excellent mixture is composed of only the finest Dwarf Growing Recleaned Grass Seeds, mixed in proper proportions. This mixture is the same as is used in our Milwaukee Public Parks. Prepaid, $1 / 2 \mathrm{lb}, 20 \mathrm{c}, \mathrm{lb}$ $35 \mathrm{c}$, peck $\$ 1.10$; not prepaid, per $1 / 2$ lb. $15 \mathrm{c}$, per lb. 25c, per peck $(31 / 2$ lbs.) $80 \mathrm{c}$, per bushel (14 lbs.) $\$ 3.00$, per 4 bushels (enough for one acre) $\$ 10.50,100 \mathrm{lbs}$. $\$ 19.00$.

\section{THISTLEINE.}

\section{A LAWN NECESSIT.}

Thistleine Destroys Canadian and Russian Thistles, Burdock, Dandelion, Johnson Grass, Mullen, Plantain, Wild Lettuce and Onions, Milk 11 eed, Sand Burs, Poison Ivy and all Other Fibrous Plants.

Ex.-Mayor Carson Writes as

Gentlemen:--'This city of La Porte, Ind., has used Thistleine and find that it completely destroys stalk and root of all noxious weeds of every description. Respectfully,

$$
\text { F. R. CARSON, }
$$

Ex-Mayor, La Porte, Ind PRICES.

Pint Bottles (Fluid) including dropper for applying to weeds in lawns, $50 \mathrm{c}$

Five Ponnd Cans. Makes 5 gallons fluid, $\$ 2.00$.

Directions with each Bottle or Can.
"Verrace S.d" Lawh Grass. A special mixture of grasses best suited for sowing on terraces, railroad embankments and side hillsgrasses that produce strong spreading roots, thus preventing heavy rains from washing them out; that will withstand drouth and exposure, thrive on shallow soils, and at the same time produce a rich, velvety green turf throughout the season. Prepaid, 1/2 lb. 25c, lb. 50c, peck $\$ 1.70$; not prepaid, per lb. $40 \mathrm{c}$, peck (31/2 lbs.) $\$ 1.40$, bu. (14 lbs.) $\$ 5.60,4$ bu. $\$ 18.00$.

"Whady Nork" lawn Grass.

On nearly all lawns there are unsightly bare spots under the shade trees, which have baffled all efforts to get into grass, but with this mixture there need be no further difficulty. Prepaid, $1 / 2$ lb. 30c, lb. 50c, peck $\$ 1.70$ : not prepaid, per $1 / 2 \mathrm{lb}$. $25 \mathrm{c}$, per lb. $40 \mathrm{c}$, per peck $(31 / 2 \mathrm{lbs}$.) $\$ 1.40$, per bushel (14 lbs.) $\$ 5.00$, per 4 bushels $\$ 18.00$, per $100 \mathrm{lbs}$. $\$ 33.00$. 


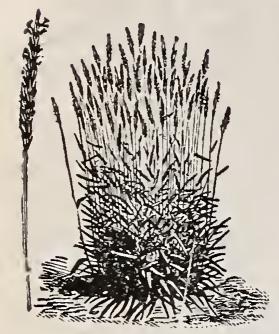

\section{WERNIGH'S RECLEANED GRASS SEEDS}

FALL SOWING IS THE MOST SUCCESSFUL.

The fall seeding of grass and clover seeds is to be specially recommended. Grass and clover seeds sown in the fall by themselves, and not with a grain crop, will make a good crop the following season. This method of sowing is also to be strongly recommended on accoun of securing a much better stand of grass and clorer. Then, too, you get a crop of grass much earlier. If, however, a grain crop is desired, we advise the sowing of it at about one-fourth the usual quantity used when sown alone. September is the best month in the fall for seeding grasses and clover. Much depends on the weather. Tow land, which is under water in spring, should "only" be seeded down in fall.

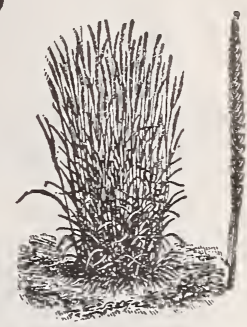

Timothy -(Phleum Pratense.) Lieschgras. Valuable as a hay crop, bringing higher prices on the market than any other hay in the world.

Fancy No. 1 -Prepaid, per lb. 20c; not prepaid, per 1b. $10 c$ peck 65s, bu. (45 lbs.) \$2.30. 100 lus \$5.00. Choice No. 1-Prepaid, per lb. 15c: not prepaid, per 1b. $7 \mathrm{c}$, peck $60 \mathrm{c}$, bu. $\$ 2.20,1001 \mathrm{bs}$. $\$ 4.25$.

Awnless Brome Grass-(Bromus Inermis.) Riesentrespe. Will grow where other grasses will perish. Just the thing for our sterile and acid plains of our Western States. Its forage has a high nutritive ralue. By mail. 25c per lb. postpaid. Not prepaid, 1 lb. $15 \mathrm{c}$ bu. $\$ 1.75,100$ lbs. $\$ 11.00$.

Bromus Mollis. - "Soft Brome Grass." Weiche Trespe. W'ill grow on almost any kind of soil. It flowers in June. Làrgely used in Europe. Prepaid, per lb. 25c not prepaid, per lb. $15 \mathrm{c}$, bu. $\$ 1.65,100$ lbs. $\$ 10.50$

Bermuda Grass. - (Cynodon Dactylon.) An excellent rariety for warm Southern country. Per pkt. 5c; oz $10 \mathrm{c}, 1 / 4$ lb. $20 \mathrm{c}, 1 \mathrm{lb}$. $75 \mathrm{c}, 5 \mathrm{lbs} . \$ 3.00$.

Canadian Blue Grass. - (Poa Canadensis.)

Canadisches Rispengras. An excellent rariety for pasturage. Prepaid, per lb. 25c; not prepaid, ner $1 \mathrm{~b}$. $15 \mathrm{c}$ bu. (14 lbs.) $\$ 1.40,100 \mathrm{lbs}$. $\$ 8.50$.

Creeping Bent. - Agrostis Stolonifera.) Fioringras. Nothing better for deep, rich and moist soils. Yalu able for pasturage. Prepaid, per lb. 30c; not prepaid, per lb. 20c, bu. (14 lbs.) $\$ 2.50,100$ lbs. $\$ 16.50$.

Crested Dos's Tail. -(Cynosurus Cristatus.) Kammgras. Withstands drouth and does well on dry land. Either for pasture or lawn purposes. Prepaid, per lb. 45c; not prepaid, per lb. 35c, bu, (14 lbs.) \$3.๖. lbs. $\$ 26.50$.

English Rye Grass. -(Lolium Perenne.) Englishes Raigras. One of the best for permanent pastures and meadows. Prepaid, per lb. 20c; not prepaid, per lb. $10 \mathrm{c}$, bu. (14 lbs.) \$1.20, $100 \mathrm{lbs}$. \$6.45.

Fineleaved Fescue -(Festuca Ovina Tenuifolia.) Feinblaettericher Schwingel. The finest bladed grass valuable only for lawns and pastures. r'repaid, per lb. $40 \mathrm{c}$; not prepaid, per lb. 30c, bu. (14 lbs.) \$4.00, $100 \mathrm{lbs}$ $\$ 28.00$.

Fowl Meadow. -(Poa Serotina.) Spaetes Rispengras. Grows rapidly and is raluable for low lands. Prepaid, per lb. 40c; not prepaid, per lb. 30c, bu. (1t lbs.) $\$ 3.75,100 \mathrm{lbs}$. $\$ 25.00$.

Hard Fescue.-(Festuca Duruscula.) Harter Schwingel. Excellent rariety for dry soils, and in appearance similar to Sheep Fescue. Prepaid, per lb. 25c: not prepaid, per lb. $15 \mathrm{c}$, bu. (14 lbs.) $\$ 1.60,100$ lbs. $\$ 12.25$.

Italian Rye Grass.-(Lolium Italicum.) Italienisches Raigras. Good for any soil. Immense yielder. Prepaid, per lb. 20c; not prepaid, per lb. 10c, bu. (1t lbs. $\$ 1.25,100$ lbs. $\$ 6.50$.

Johnson Grass.-(Sorghum Halpense.) Johnsongras. It wil stand great heat and severe drouth, and is liked well by all kiuds of stock. Prepaid, per lb. 25c; not prepaid, per b. $15 \mathrm{c}$, bu. (25 lbs.) $\$ 2.50,100$ lbs. $\$ \$ .9$.

Kentucky Blue Grass.-(Poa Pratensis.) Wiesen Rispengris. Better known as June Grass. It is adaptable to all climates and soils.

Fancy No. 1-Recleaned. Prepaid, per lb. 25c; not prepaid, per lo. $15 \mathrm{c}$, bu. (1t lbs.) $\$ 2.00$ 100 lbs. $\$ 12.50$ Choice No. 2-Nore chaffy than the fancy. Prepaid, per $1 \mathrm{~b}$. $20 \mathrm{c}$; not prepaid, per $1 \mathrm{~b} .12 \mathrm{c}$, bu. (14 1bs.) $\$ 1.45,100$ lbs. $\$ 8.50$.

Meadow Fescue.-(Festuca Pratensis.) Wiesenschwinged. This variety should not fail to be in all permanent pastures.

No. 1 Fancy-Prepaid, per lb. 20c; not prepaid, per lb. $12 \mathrm{c}$, bu. $\$ 1.45,100$ bs. $\$ 8.50$

Meadow Foxtail-(Alopecuras Pratensis.) Wiessenfuchs. chwanz. A perennial valuable for permanent pastures. Fancy No. 1-Prepaid, per lb. 35c; not prepaid, per lb. $25 \mathrm{c}$, bu. (14 lbs.) \$3.35, 100 lbs. $\$ 21.00$.

Common No. 2-Prepaid, per lb. 30c; not prepaid, per lb. 20 c, bu. $\$ 2.65,100$ lbs. $\$ 18.00$
Orehard Grass.-(I)actylis Glomerata.) Knaulgras. This is the best and one of the earliest pasture grasses known.

Fancy No. 1-Northern grown seed. Prepaid, per $1 \mathrm{~b} .30 \mathrm{c}$ llot prepaid, per lb. 20c, bu. (14 lbs.) $\$ 2.10,100$ lbs $\$ 13.50$

Common No. 2-Grood seed, but contains some English Rye Grass. Prepaid, per lb. 25c; not prepaid, $15 \mathrm{c}$, bu. (14 lbs.) $\$ 1.75,100$ lbs, $\$ 11.00$

Red Fescre. -(Festuca Rubra.) Rother Schmingel. A good rariety for pasture, also used for lawns. Prepaid, per lb. 30c; not prepaid, per lb. 20c, bu. (1t lbs.) $\$ 1.95$. 100 lbs. $\$ 12.50$.

Red Top. - (Agrostis Vulgaris.) Rother Schringel One of the best known rarieties, adaptable to almost any kind of soil.

Fancy No. 1-Recleaned seed. Prepaid, per lb. 25c; not prepaid, per lb. $15 \mathrm{c}$, bu. (1t lbs.) $\$ 1.95,100$ lbs. $\$ 11.50$. Choice No. 2-Contains a little chaff. Prepaid, per lb. 20 c; not prepaid, per lb. 10c, bu. (14 lbs.) $\$ 1.15,100$ lbs. $\$ 8.50$.

Common No. 3-Such as is sold in feed stores. Prepaid, per lb. 15c; not prepaid, per lb. 6c, bu. (1t lbs.) 85̃c, 100 lbs. $\$ 4.25$.

Rough Stalked Meadow.-(Poa Trivalis.) Raues Rispengras. Used mostly on low, damp soils. Prepaid per lb. 40 c; not prepaid, per lb. $30 \mathrm{c}$, bu. (14 lbs.) $\$ 3.85$, 100 lbs. $\$ 24.00$.

Sheep's Fescue.-(Festuca Ovina.) Schaf Schwingel. A farorite for sheep pasturage. Withstands drouth. Fancy No. 1-Prepaid, per lb. 30c; not prepaid, per lb. $20 \mathrm{c}$, bu. (14 lbs.) $\$ 1.95,100$ lbs. $\$ 12.50$.

Sweet Vermal, Anumal.-(Anthoxanthum Puelli.) Einjaeriches Geruchgras. Used in all meadows and pastures. Owes its name to its sweet odor when in bloom. Prepaid, per lb, 25c; not prepaid, per $1 \mathrm{~b}$. 15c, bu. (14 lbs) $\$ 1.75,100$ lbs. $\$ 11.50$

weet Vernal, Perennial or True.-(Anthoxanthum Odoratum.) Peremnirendes Geruchgras. A good villiety for use in all permanent meadows and pastures. Frepaid, per lb. $\$ 1.10$; not prepaid, per lb. $\$ 1.00$.

Ta11 Fescue. - (Festuca Elatior.) Rohrschwingel. A good producing rariety on low land. Prepaid, per lb. $40 \mathrm{c}$; not prepaid, per lb. $30 \mathrm{c}$, bu. (14 lbs.) $\$ 3.75,100$

Tall Meadow Oat.-(Avena Elatior.) Franzoesisches Raigras. A rapid grower and an abundant yielder. Ought to be in all permanent meadows. Prepaid, per lb. 35c; not prepaid, per lb. 25c, bu. (14 lbs.) \$2.75, 100 lbs. $\$ 17.00$

Various Leaved Fescue.- (Festuca Heterophylla.) Wechselblaettericher Schwingel. Valuable for pastures and lawns. Prepaid, per lb. 35்c; not prepaid, per lb. $25 \mathrm{c}$, bu. (14 lbs.) $\$ 3.00,100$ lbs. $\$ 19.00$.

Water Fescue. (Glyceria Fluitans.) Mannaschwadengras. Valuable for improring marshes and low lands in general. Prepaid, per lb. 35c; not prepaid, per lb. $25 \mathrm{c}$, bu. (14 lbs.) $\$ 2.90,100$ lbs. $\$ 20.00$.

Water Meadov -(Glyceria Aquatica.) Quelischwaden. of great value for low land, which is more or less under water at times. Grows rank and coarse, still it is nutritious and well liked by cattle. Prepaid, per lb. $40 \mathrm{c}$; not prepaid, per lb. $30 \mathrm{c}$, bu. (14 lbs.) \$3.25, 100 lbs. $\$ 23.00$.

Wood Hain Grass.-(Aira Flexuosa.) Waldgras. Is hardy, and also grows in the dryest regions. Does as well in shady places. It is not of much ralue for hay. Prepaid, per lb. 25c; not prepaid, per $1 \mathrm{~b}$. $15 \mathrm{c}$, bu. (14 lbs.) $\$ 1.75,100$ lbs. $\$ 10.50$

Vood Meadow.-(Poa Nemoralis.) Hainrispengras. A good rarietr for pasturage in shady places. Also a good variety for shady lawns. Prepaid, per $1 \mathrm{~b}$. $45 \mathrm{c}$ not prepaid, per lb. $35 \mathrm{c}$, per bu. $\$ 4.50,100$ lbs. $\$ 28.00$ Wooly Soft Grass. - Holcus Lanatus.) Honig Gras. Till grow on any soil, especially low land for meadows. Prepaid, per lb. 25c: not prepaid, per lb. $15 \mathrm{c}$, bu. (14 lbs.) \$1.95, 100 lbs. $\$ 12.00$.

Yellow Oat Grass. - (Avena Flavescens.) Goldhafer. An excellent variets far pastures and meadows. Prenaid, per lb. $65 \mathrm{c}$; not prepaid, per lb. $55 \mathrm{c}$, bu. (14 lbs.)
$\$ 7.00$. 


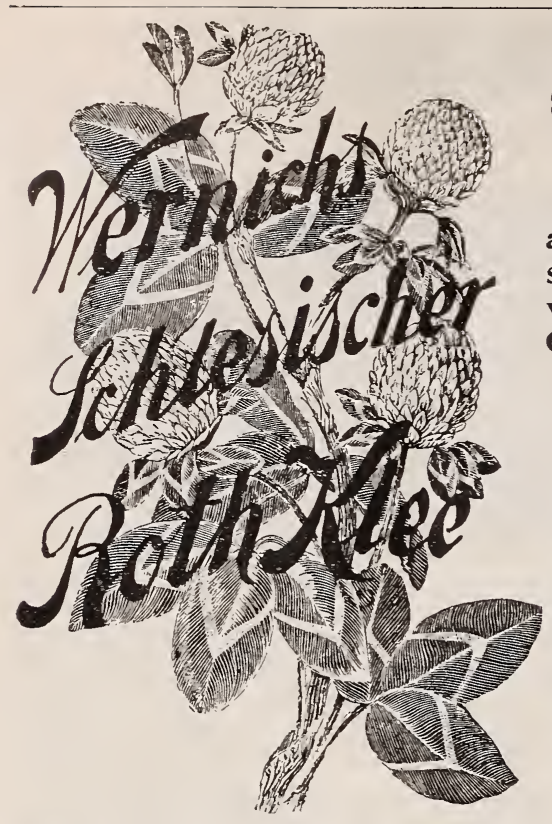

S $\frac{\text { The Cliver for Sandy Solis }}{\overline{A N D} \text { LUCERN }} \mathrm{E}$

Medicago-Falcato-Sativa.

Unquestionably the Greatest of all the Varieties of

\section{ALFALFA}

And Certainly the Greatest Hay-Producing Clover ever introduced.

of it, the Michigan Experiment Station Bulletin No. 181, speaks: We wish we could impress upon every one of our customers the great value of Sand Luzerne, particularly as a crop to depend upon n drought suffering localities. It is positively dronght resisting and any farmer who has ever seen the difference in vield and appearance between a field of Sand Luzerne

\section{OTHER VARIETIES OF CLOVER.}

Alsyke or Sredish.-(Trifolium Hybridum)-Schwedischer Klee.

Choice No 1- Vorthern Gromn seed Prepaid, ver lb. 30c; not prepaid, per lb. 20 c, peck $\$ 2.60$, bu. $\$ 9.50,100 \mathrm{lbs}$. $\$ 14.50$.

Cominon No. 2-1'repaid, per lb. 25c; not prepaid, per lb. $15 \mathrm{c}$, peck $\$ 2.15$, bu. $\$ 7.80,100 \mathrm{lbs}$. $\$ 12.50$.

Bokhora.-(Meliotus Alba)-Honigklee-Prepaid, per lb. 30e; not prepaid per 1 b. 20 c, peck $\$ 2.75$, bu. $\$ 10.20,100 \mathrm{lbs}$., $\$ 16.50$

Crimson,-('Trifolium Incarnatum)-An annual variety, mostly used in the South, where it wan be sown in the fall with success, but if suwn in the North, not before spring. It produces enormous crops. Pre. paid, per 1b. $25 \mathrm{c}$; not prepaid, per lb. $15 \mathrm{c}$, peck $\$ 1.65$, bu. $\$ 6.00,1.0$ lbs. $\$ 9.75$.

Mammoth.-(Trifolium I'ratense Perenne)-Riesen Rothklee.

Choice No. 1-Prepaid per lb. 28c; not prepaid, per lb. 18c, peck $\$ 2.40$, bi $\$ 9.00,100 \mathrm{lbs} \$ 14.25$.

Common No. 2-Prepaid, per lb, 25c; not prepaid, per lb. 15c, peck \$2.25, bu. $\$ 8.40,100$ lbs. $\$ 13.75$.

Red or Jnne.- ('Trifolium I'ratense) Rothklee.

Choice No. 1-Prepaid, per lb. 28c; not prepaid, per $1 \mathrm{~b}$. $18 \mathrm{c}$, peck. $\$ 2.40$ bu. $\$ 8.40,100$ lbs. $\$ 13.75$.

Common Red No. 2-Prepaid, per lb 25c; not prepaid, per lb. 15c, peck $\$ 2.25$, bu. $\$ 7.20,100$ lbs. $\$ 13.00$

White.-('lnifolium Repeus)-Weissklee.

Fancy No. 1-Prepaid, per lb. 35c; not prepaid, per lb. 25c. peck \$3.25 bu. $\$ 12.50,100$ lbs. $\$ 19.50$.

Common No. 2-Prepaid, per lb. 30c; not prepaid, per $1 \mathrm{~b}$. $20 \mathrm{c}$, peck $\$ 2.75$, bu. $\$ 11.00,100$ lbs. $\$ 17.75$.

Yellow--(Vedicno Luprina)-Gelb oder IIonatsklee Can be cut three times a year Cultivate like Red Clover. I'repaid, per lb. 25c; not prepaid, per lb. $15 \mathrm{c}$, peck $\$ 2.00$, bu. $\$ 6.75,100 \mathrm{lbs}$. $\$ 10.50$.

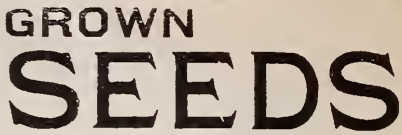

ket Fluctuations.

Owing to its liability to be winter killed it is not advis= to with such Grasses as are adapted to their land. See SILESIAN RED CLOVER.

Frost Won't Kill It:

and acknowledged fact that Medium Red or June a far the most important of all Clover

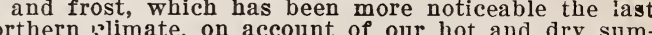
Drought nor frost will affect our SILESIAN

alde red excepting that blossorns

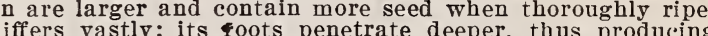

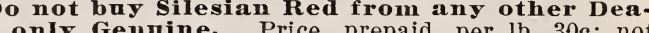

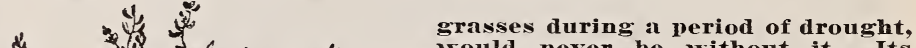
would never be without it. Its pearance during drought, when eversthing else appears dry and brown, is a sight to behold. Prepaid, per lb. $35 \mathrm{c}, 3$ lbs. $\$ 1.00$; not prepaid, per lb. $25 \mathrm{c}$, peck $\$ 3.25$, bu. $\$ 12.00,100$ lbs. $\$ 18.90$.

\section{American Alfalfa.}

(Medicago Sativa.)

Especially adapted to dry climates and soils. Thrives on light, sandy and loamy soils. Immense yielder; 3 to 5 cuts a rear after once established. Prepaid, per lb. 30c; not prepaid, per lb. 20 c, peck $\$ 2.25$, bu. $\$ 8.40,100 \mathrm{lbs}$. $\$ 13.50$.

\section{Salauer Luzerne.}

\section{(Medicago Sativa.)}

Grown from seed Imported from Europe. Being raised in the north, farmers will do well to gire SALAUER ALFALFA the preference orer our western grown Alfalfa Seed. Prepaid, per $1 \mathrm{~b} .30 \mathrm{c}$; not prepaid, lb 20c, peck $\$ 2.70$, bu. $\$ 10.00,100$ Ibs. $\$ 16.00$

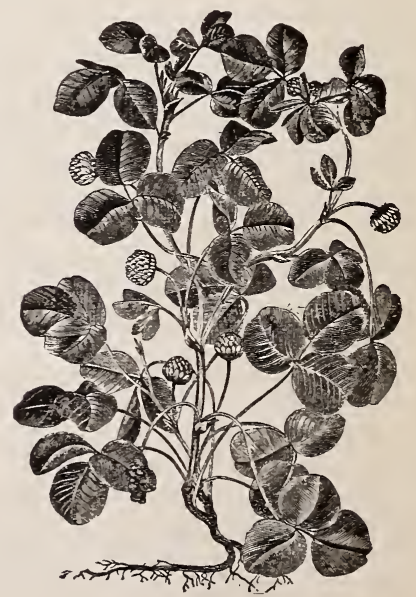

Yellow Clover. 


\section{WERNICH'S SPECIAL GRASS MIXTURES}

\section{FOR PERMANENT MEADOWS AND PASTURES.}

Why are our Clover-Crass Mixtures best Adapted for Permanent Pastures and Meadows and how can these be best obtained?

It is a well established fact that a judiciously selected mixture of several varieties of frass and Clover Seeds will produce a much larger yield-generally again as much per acre than can be obtained with only one or two kinds sown alone. In sowing a larger variety you are not running the risk ot not securing a stand at all, as you would by sowing one or two kinds only, for in a larger variety there must be at least several kinds of grasses adapted to your coil, while if you sow only one kind this may not be at all adapted and consequently no result. A pasture with a variety of grasses and clover is again as productive and earlier than if but one kind of grass is used, and can also be pastured throughout the season, as most grasses used are deep-rooted and are extremely drought-resisting.

Many varieties sown together for a meadow or for hay cover the ground very closely and a larger vield of hay of much better quality can always be obtained from a mixed meadow. What we have said above in regard to grasses being deep-rooted and drought-resisting, also applies to the grasse use for permanent meadows.

In a great many parts of the country only one or two kinds of grasses are known and mostly sown and these are Timothy and Clover. While Timothy is a splendid Grass, and Clover the foundation of all successful farming, both are not permanent, and not well adapted for pasturing alone, as they are easily affected by drought or frost, thereby making it necessary to re-sow every year or two-a rather expensive method. In our carefully selected Clover-Grass Mixture several varieties of the Natural Grasses are sown together, and these will cover the ground very closely and make three spears of grass grow where formerly but one grew; besides, these Clover-Grass Mixtures will stand various climatic and soil conditions better, will last longer or be permanent, and yield at least double the quantity of hay that is secured from ordinary fields sown with Timothy and Clover.

\section{A-Mixtures For Permanent Meadows.}

No 1. For High and Dry Land, Rather Light No 1, Poor Soil.

Meadow Fescue English Rye Mammoth Clo'r Red Fescue Sweet Vernal Red Clover Crested Dogtail Canada Blue Alfalfa Orchard Grass Red Top Timothy

Price Lb. 10c; 25 lbs. $\$ 2.45 ; 50$ 1bs. $\$ 4.60$; 100 lbs. $\$ 9.00$.

No. 3 For Low and Moist Land, Good and Mead'w Foxtail Sweet Vernal Tall Mead. Oat Orchard Grass Meadow Fescue Alsike Red Top Canada Blue Timothy

Price Lb. 13c; 25 lbs. $\$ 3.25 ; 50$ lbs. $\$ 6.30$; 100 lbs. $\$ 12.50$

No. 5 For wet Bottom Land. Land oceaNo. 0 , For wet sionally overflowed.

Tall Fescue Meadow FescueKentucky Blue Tancisa Blue Alsike Mead'w Foxtail Red Top Timothy Price Lb. 13c; 251 lbs. $\$ 3.25 ; 50$ lbs. $\$ 6.30$;
No, 2, For High and Dry Land, Heavy or Tall Mead. Oat Canada Blue Sweet Vernal Orchard Grass Kentucky Blue Red Clover $\begin{array}{lll}\text { English Rye Red Top } & \text { Alsike Clove } \\ \text { English Blue Italian Rye Timothy }\end{array}$

Price Lb. $12 \frac{1}{2} \mathrm{c} ; 25$ lbs. $\$ 3.00 ; 50$ lbs. $\$ 5.75$

No, 4, For Peat and Boggy Land. Marshy No. 4. For peat and Sticky Soil.

English Rye Red Top Red Clover Mead'w Foxtail Canada Blue Alsike Clover Meadow Fescue Kentucky Blue Timothy Price Lb. $12 \frac{1}{2} \mathrm{c} ; 25$ lbs. $\$ 3.00 ; 50$ lbs. $\$ 5.75$ No, 6, For Marsh and Swamps. Low Land

Water Meadow English Rye Creeping Bent Water Fescue Red Top Canada Blue Tall Fescue Meadow Fescue Alsike Clover Price Lb. $16 \mathrm{c} ; 25$ lbs. $\$ 4.25 ; 50$ lbs. $\$ 8.00$; 100 ibs. $\$ 15.75$.

\section{$B_{-1}$ Mixtures For Permanent Pastures.}

A good pasture is a necessity on every farm. It should be permanent and the grasses used should be early medium and late, so as not to mature all at the same time, thus furnishing continuous grazing the entire season. Such varieties should be used that are good sod formers. Our Mixtures are composed of such grasses. No, 7. For High and Dry Land. Rather Red Top Hard Fescue Red Fescue Canada Blue Alsike English Rye Red Clover

Price Lb. 10c; 25 lbs. $\$ 2.45 ; 50$ lbs. $\$ 4.60$; 100 ibs. $\$ 9.00$.

No. 9. For Low and Moist Land. Good and Soft Meadow Rough S. Mead. English Rye Soft Meadow Rough Sent Timothy Kentucky Blue Creeping Bent Timothy
Tall Fescue Fowl Meadow Red Clover Red Top $\quad$ Italian Rye Alsike

Price Lb. $12 \frac{1}{2} \mathrm{c} ; 25$ lbs. $\$ 3.00 ; 50$ lbs. $\$ 5.75$; 100 lbs. $\$ 11.25$.

No 11 For Marshy and Swampy Land. Land No 11. For Miser Water.

Water Meadow Water Fescue Canada Blue Tall Fescue Creeping Bent Kentucky Blue Meadow Soft Ped Top Leaved Fescue English Rye Meadow Fescue Alsike

Price Lb. 121/2 c; 25 lbs. $\$ 3.00 ; 50$ lbs. $\$ 5.75$

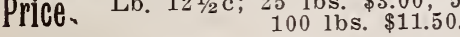

No 8. For High and Dry Land. Rich and Heavy Soil.

Kentucky Blue Tall Mead. Oat Red Clover Orchard Red Fescue White Clover English Rye Canada Blue Alsike Italian Rye Mead. Foxtail Timothy

Price Lb. 10c; 25 lbs. $\$ 2.45 ; 50$ lbs. $\$ 4.60$ 100 lbs. $\$ 9.00$ No. 10. For Peat and Boggy Land. Marshy

Mead. Foxtail Rough S. Mead. Red Top Meadow Fescue Tall Fescue Canada Blue Creeping Bent Kentucky Blue Italian Rye Fowl Meadow English Rye Alsike

Price Lb. 15c; 25 lbs. $\$ 3.50 ; 50$ lbs. $\$ 6.75$ N0. 12. For Orchards or Shady Places. Good

Wood Hair Wood Meadow Fall Mead. Oat Orchard Red Top English Rye Kentucky Blue Canada Blue White Clover Crested Dogtail Sweet Vernal Alsike Clover Price Lb. $12 \frac{1 / 2 \mathrm{c} ;}{100} \mathrm{lbs}$. $\$ 11.50$ 


\section{WI T TER WHEA T.}

To Every 21/2 Bu., or Less, Add 15e for a New Bag.

\section{OUR SEED WHEAT}

Careful selection in the field is supplemented by careful, thorough cleaning and grading in the house by the best machinery. We remore the imperfect grains and weed seeds, often to the extent of 10 to 20 per rent. leaving for our customers only the heavy, perfectly developed seeds, which possess the greatest vitality and produce the most abundant crops.
SO CENT OR \$1.OO WHEAT.

If the price is low you must raise a big crop to make a profit. If the price is high the probability is that the crop is a short one, and jou must sow a hardy, vigorous variety to insure a good crop when jour neighbor has a short one. The sure cropper, yieldy variety of wheat insures a profit nearly erery year. If such seed is backed
up with good cultivation, there is money in growing wheat.

Our Seed Wheat will produce 30 to 50 bushels per acre, as certainly as the ordinary Elevator or No. 2 Wheat will produce 15 to 20 bushels.

\section{THREE GRAND NEW VARIETIES.}

\section{PULTZO-MEDITERRANEAN.}

\section{(BEARDLESS)}

This is a most certain cropper under all conditions. It has been thoroughly tested and survires when others fail. It is ALMosT AS HARDY AS RYE.

The Fultzo-Mediterranean was originated by crossing the Fultz on the Hybrid-Meditarranean. on the Hrbrid-Meditarranean. Hence the name and al experiknowledge the parents as being among the hardiest, most reliable and most valuable varieties of wheat ever grown in this country. A beautiful rariety in growth, straw, head and grain. The plant is a very strong grower with a corresponding large root development. If sown thinly it will stool out wonderfully from

40 io over 100 slalks irom a fiain.

For this reason, if wheat is damaged, the stalks that are left will do their full duty in multiplying to take the places of their fallen comrades. Farmers, by all means sow a vigorous rariety of wheat, with great recuperitive properties, and you will have bushels of grain and dollars for jour pains when harrest romes.

The stalks are large and rery stiff, of medium height, with thick, broad heads of good length. The heads are broader at the top than at the bottom, looking at them edgewise. The meshes are compact and contain from three to fire grains in ordinary seasons with common cultiration, while it it not uncommon to find heads with 150 grains, bearing five to seren grains to the mesh. Chaff white, heads smooth or beardless, grain large, color red, rery heary.

Prepaid, per 1b. 25c, 3 lbs. 60c: not prepaid, peck $50 c$, bu. $\$ 1.75,21 / 2$ bu. (for 2 acres) $\$ 4.25,5$ bu. $\$ 8.00$ 10 bu. $\$ 15.50$

\section{FLY PROOF ANTI RUST.}

\section{(BEARDED.)}

From an experience of four years with this new wheat in valious localities we consider it the finest bearded wheat offered, and we have had dozens of voluntary testimonials. which will endorse this statement. The name is an unusual one but it is a fair description. There is no other rariety that we know that is as hardy or capable of withstanding adverse conditions. It is the finest and heaviest grain and has yielded by actual test by the side of other well known sorts fully 10 per cent. more ially recommend this wheat for medium land and believe it will give utmost satisfaction wherever used. Prepaid, per 1b. $25 \mathrm{c}, 3 \mathrm{lbs}$. $60 \mathrm{c}$; not prepaid, peck $60 \mathrm{c}$, bu. $\$ 1.85,21 / 2$ bu. $\$ 4.50,5$ bu. $\$ 8.75,10$ bu. $\$ 16.50$.

\section{HARVEST KING.}

\section{(BEARDLESS)}

In the past it has surprised all who have sown it in withstanding severe winters, great droughts in spring and summer, making good crops when many other kinds were failures. In the five years since its introduction, on many farms it was the only kind worth hervesting.

The roots are largely developed and hold firmly to the soil which fact allows it to draw food from the soil should dry weather prevail, also makes it better able to withstand attacks from insects.

The plants or stalks are tirmly built from the ground up, and withstand ordinary storms. We don't recommend it to stand up against tornadoes, but against all ordinary happenings. We want to state facts about this wheat, and when the crop is harvested our customers will be able to say, "It is Just as Recommended. Heads are large; length

F!om 4106 inches. Well Filled.

The shelled grain weighs rery heary, and from the fact that it almost invariably fills up plump and sound, a low grade of wheat is almost unknown with this reriets. Its milling qualities are all that can be desired-A No. 1 - and sought after by mitlers.
For yield the Harvest King can be depended upon alFor yield the Harvest King can be depended upon al-
most erery year. In farorable seasons. 50 bushels per acre is not beyond its usual capacity, although 30 to 40 bushels is about its average rield in ordinars seisons, under ordinary conditions. For a steadr pull it can be depended on sear after year. Prepaid. per $1 \mathrm{~b}, 25 \mathrm{c}, 3$ the $60 \mathrm{c}$; not prepaid, peck 50c, bu. $\$ 1.75,21 / 2$ bu. (for 2 acres) $\$ 4.25,5$ bu. $\$ 8.00,10$ bu. $\$ 15.50$.

\section{EARLY RED CLAWSON.}

\section{BEA PDLESS. )}

An excellent wheat for the northern climates

Mr. P. M. Swartz, of Waukesha, Tis., writes about this wheat as follows:

Traukesha. Wis.. July 18, 1906.

Ternich Seed Co.. Milwaukee. Tis. The Early Red Clawson Winter Wheat is a bald height. standing up well in storms. Heads are always filled to the end with a heautiful round and plump berry, rielding on well prepared land from 42 to 4 s bushels per acre, in a farorable season. I have grown this wheat for the past fifteen years against other rarieties and found none to equal it in rield or hardiness. It is fully acclimated and instead of "running out." as other kinds do, it is improving in its good qualities. It has taken prizes at the Torld's Fairs of Chicago, 1893 , and St. Louis, 1904 Every farmer growing should give it a trial and be convint.
Iours truly.

Prepaid, ib. 25c, 3 lbs. $60 \mathrm{c}$; not prepaid, peck $50 \mathrm{c}$ ьu. $\$ 1.50$, डे bu. $\$ \tau .00,10$ bu. $\$ 13.50$. 


\section{ORDER SHEET FOR SEEDS Bulbs, Implements, Tools, Fortilizers, ORDER SHEET FOR SEESS Insecticides, Poultry and Bee supplies WERNICH SEED CO., MILWAUKEE, WIS.}

More order blanks will be sent on request. Always write letters on a separate sheet from your order.

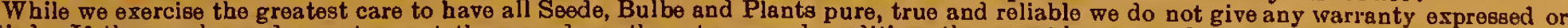

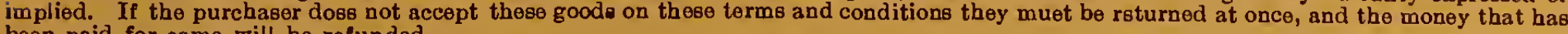
been paid for eame will be refunded.

VERY IMPORTANT.-Write your name very plainly, and give your Post Office, County and State in full every time.

Your Name.

\section{(Vers plain.)}

Post Office

County

State

Street

P. $0.80 x$

Rural Route

Express Office \{ If different \{

Gardener's Name.

Please read How to Order (inside cover page) before ordering, and avoid any mieunderetanding.

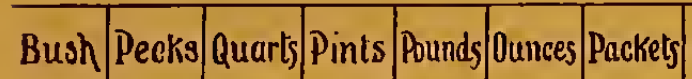

\begin{tabular}{l|l|l|l|l|l|l|}
\hline Bush & Pecks & Quarts & Pints & Pounds & Ounces & Packets \\
\hline & & & & & & \\
\hline & & & & & & \\
\hline & & & & & & \\
\hline & & & & & & \\
\hline & & & & & & \\
\hline
\end{tabular}

\section{AMOUNT ENCLOSED.}

No Goods Sent C. 0 . D. LOOSE MONEY IS NOT SAFE.

state how much money you enclose. Meke money orders or checks peyahle to Wernich Seed Co.

Money Order - \$...........

Draft or Check $\$ \ldots . . . \ldots \ldots$

Postage Stamps $\$$............

Cash $\quad$. $\$ . . . . . . .$.

Please forward Goods by $\left\{\begin{array}{c}\text { Mail, Freight } \\ \text { or Express }\end{array}\right\}$

Shipped by $\ldots \ldots \ldots \ldots \ldots$

Transferred..............

Filled

Clerk

Pleese do not write here.

Received.................

190 PRICE

NAMES OF ARTICLES WANTED

Brought forward 


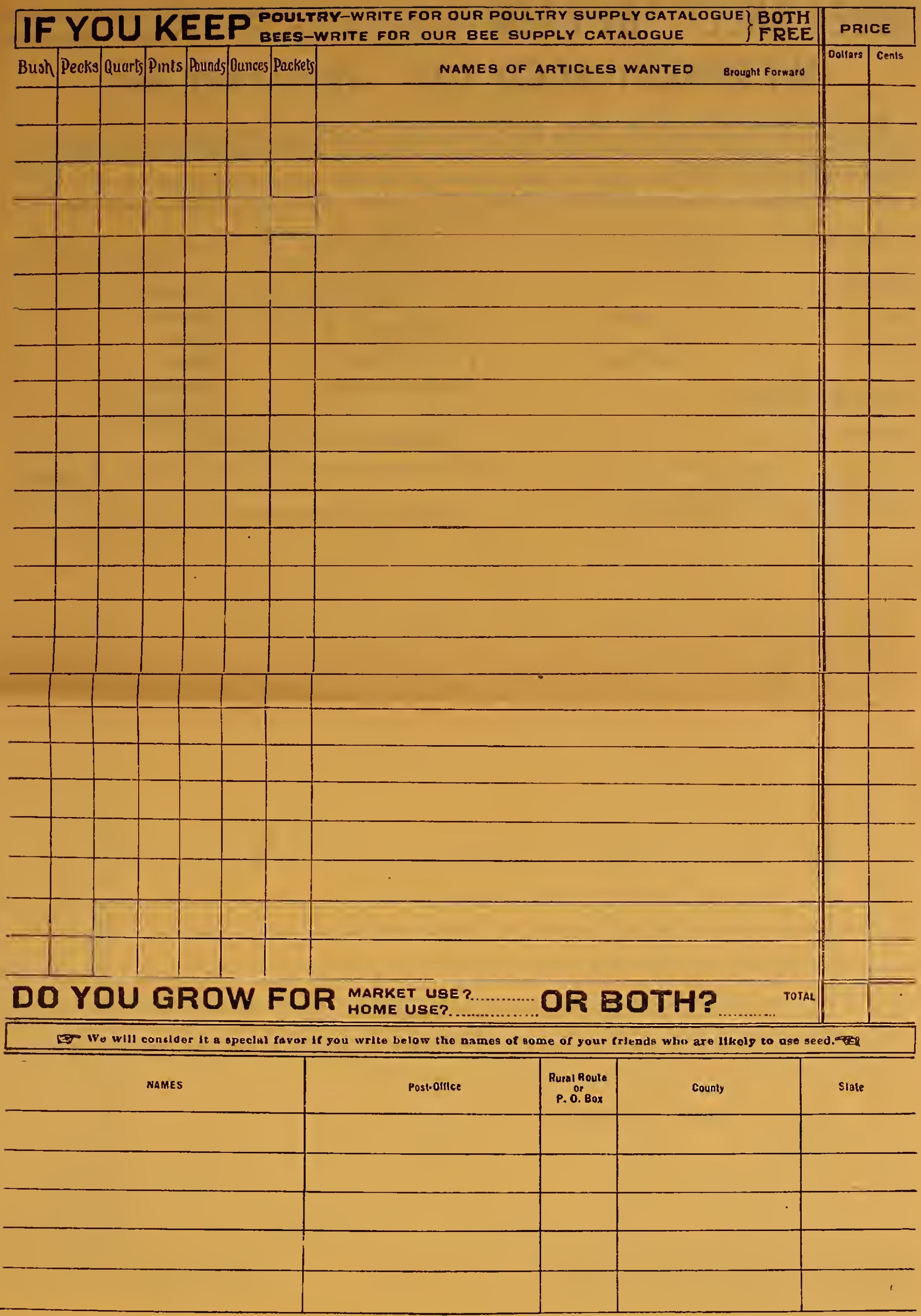




\section{WINTER GRAIN.}

\section{ST. JOHN'S RYE.}

The beauty of this Rye is, that it can be sown either in Spring or Fall, pastured and the following Season pastured again, or harrested for grain. Introduced in this country 20 years ago, by us, this Rye has giren splendid satisfaction as a money maker. The demand exceeds the supply every year, and two years ago we turned down order after order for this splendid Rye. This is undoubtedly the only Rye to sow, especially as a catch crop. None so prolific in straw or kernels as our "Matchless St. John's." Can be sown either in Spring or Fall. The makes no difference, grow it will, wet or dry weather, and furnish abundance of fodder. If your winter wheat ar other winter crops prove a failure, we know of nothor other winter crops prove a failure, we know of nothit you will get

1. Enough for pasturing your horses and cattle until late in the season.

2. In the spring it will come up thick, early and luxuriant.

3 Can then again be used as a pasturage or by letting it run to seed, will yield 30 to 50 bushels of fime seed rye. Sown with oats and sand retches, as a catch crop, you will have fodder to burn.

If somn alone som 40 pounds to the acre.

Prepaid, $1 \mathrm{~b}, 25 \mathrm{c}, 3 \mathrm{lbs}, 65 \mathrm{c}$; not prepaid, peck $45 \mathrm{c}$, bu. $\$ 1.65,21 / 2$ bu. $\$ 3.75,10$ bu. $\$ 13.50$.

\section{PROBSTIER WHITE WINTER RYE.}

Several times during the past three rears rje has com. manded a greater price per bushel than wheat. As rye is more easily grown than wheat and also can be grown on ground that will not produce wheat, it follows that it is worthy of some special attention and whaterer improvement is made in the rield and quality of this crop is of great importance to many of our farmers.

In our Probstier White Winter Rye are embraced all the good qualities ever possessed by this important grain, and growers cannot do better than put their crop in of this sort, or at any rate sow sufficient to give them seed for future crops. It is much superior to the common rye, as usually raised. It will rield at least one-third more grain, will make flour almost as white as wheat.

Being exceedingly hardy, it can be sown in cold, exposed situations, also on ground too poor to produce wheat, with most satisfactory results. Owing to its rapid, strong growth it is a very valuable plant for fall, winter and spring pasture. Also is exempt from insect pests.

The straw, which grows very strong and long (from 6 to 7 feet high), is also very valuable and oftentimes brings as much money as the grain, thus making the crop doubly valuable.

Sow one bushel per acre.

Prepaid, per lb. $25 \mathrm{c}, 3 \mathrm{lbs}$. $65 \mathrm{c}$; not prepald, peck $40 \mathrm{c}$ bu. $\$ 1.05,21 / 2$ bu. $\$ 2.50,5$ bu. $\$ 4.85,10$ bu. $\$ 9.50$.

\section{WINTER OATS.}

Chiefly sown in the Southern and Middle States, although they have been successfully grown in New Jersey and Delaware, Pennsslvania and some portions of New Iork State Here in Wisconsin they have not been tried, at least not to our knowledge. Winter Oats are sown throughout the South, both in the fall and spring, and really from August through March. Fall seedings are better sown in August or September, or certainly before the tenth of October. Further south, howerer, they can be sown later than this. Some farmers seed Winter Oats in November or December, but usually prefer to plow them in with a single-horse plow when sown at this time. Early seedings in August are also quite oftel plowed in. Ordinarily, however, a hears harrow is sufticient to cover it. For spring seedings they can be sown in weather in January, they must be put in deeply, so as to protect them from freezes. Price fluctuates. Prepaid, per lb. 20c, 3 lbs. 50c: not prepaid, peck $40 \mathrm{c}$, bu. $\$ 1.25,21 / 2$ bu. $\$ 2.90,5$ bu. $\$ 5.75,10$ bu. $\$ 10.00$

To every $2 \frac{1}{2}$ bu. or less, add 15 cts. for a new bag.

\section{WINTER BARLEY.}

This makes really a more leafy growth than either Rye or Oats, and makes a very strong growth of most nutritious pasturage, as $\pi$ ell as a large yield of grain and should be much more largely grown throughout the South than at present. It can be constantly grazed during the winter and spring, and is ready to cut for grain two weeks ahead of wheat. It makes a fine feed for stock and poultry. It is principally recommended for fall sowing, although it gires very satisfactory results ln some sections in the spring. Should be sown at the rate of $1 \frac{1}{2}$ to 2 bushels to the acre.

Fall or winter Barley is the only kind that should be sown in the South. Spring Barley is of very little value compared with Fall or Winter Barley, as it does not make sufficient growth for grazing or a good yield of grain. Farmers should be careful in purchasing, as Spring Barley is quite often sold simply as barley throughout the South, and does not gire satisfactory results. Price fluctuates. Prepaid, per lb, $20 \mathrm{c}, 3$ lbs. $50 \mathrm{c}$ $\$ 5.75,10$ bu. $\$ 10.00$.

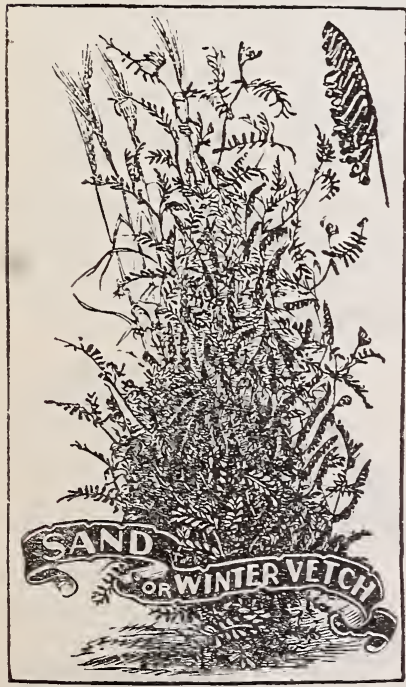

\section{SAND VETCHES. (Vicia Villosa)}

The Largest Yielding, Surest Cropping, and Most Nutritious of Winter and Spring Forage Plants. Makes Splendid Grazing, a Much Heavier Crop Than Clover, Stands Cold Weather Better and is Superior as a Soil Improver.

This raluable forage plant has proven a boon to farmers, especially those that hare had poor success with hay. Withstands serere drought, heat and cold. should be sown in August or September and they will yield a good crop by the end of April. Sow in drills or broadcast. The latter is preferable at the rate of 40 to 60 pounds per acre. Should be sown with rye or wheat to gire support to the vines. Extensively used for hog pastures. When so used the hogs cheuld be eat the vetches almost to the ground, then taken out and a second crop will soon mature, which can again be pastured or allowed to run to seed. In running to seed, they will reseed themselres and a patch can be kept for years. Should become better known. We hare sold it for the last 10 years and never hare heard of a failure to do all we claim it will. Sand Vetches are exceedingly nutritious and may be feed with safety to all kinds of stock. It is of such early and rapid growth that a full crop can be taken in time for planting spring crops. The Agricultural Department at Washington estimates its value as a fertilizer, when plowed under, as equiralent to $\$ 16.00$ to $\$ 45.00$ worth of commercial fertilizer per acre. Prepaid, per lb. 25c: not prepaid, per 1b. $15 \mathrm{c}, 5 \mathrm{lbs}$. $60 \mathrm{c}, 10 \mathrm{lbs}$. $\$ 1.25,251 \mathrm{bs}$. $\$ 2.75,100 \mathrm{lbs}$. $\$ 10.50$. 


\section{NORTHERN GROWN}

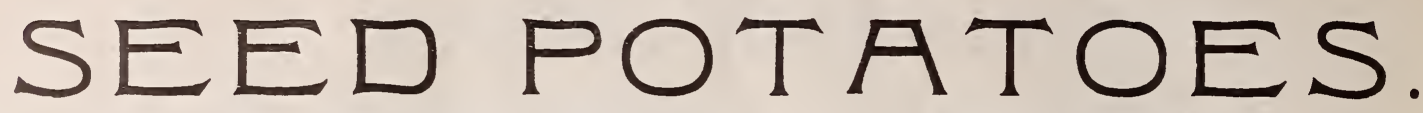

IF ORDERED BEFORE OCTOBER 1ST, I9O5.

Positively No Potatoes Shipped After Nov. Ist, or Before March 15th, Excepting at Risk of Person Ordering Same.

Our potatoes are grown in the cold North, where nature and the elements alike decline existence to all but the very hardiest varieties. They inherit those qualities that place them in the lead for Seed purposes. We make a specialty of and handle this seed only. All varieties are pure and true to name. Our prices may rule somewhat uigher than those of our competitors, but when quality and real worth are considered they will be found by far the cheapest and most remunerative to growers. Southern growers of Potatoes usually want the earliest and best Seed obtainable. Our list contains only such varieties that have been tried and not found wanting by our Southern friends and customers. We make no charge for packing or cartage. Our barrels contain $2 \frac{1}{2}$ bushels by weight (150 lbs. net). Up to and including Norember 15th we will guarantee safe arriral. After that date the weather usually is unreliable and the purchaser assumes all risks. CASH WITH ORDER.

\section{EARLY SIX-WEEKS POTATO.}

Wonderful

Ready for

Market in

Six Weeks.

Ripens in

Ten Weeks.

Yields at rate of 400 Bushel and over.

Bushel, $\$ 1.50$ Barrel, $\quad 3.50$

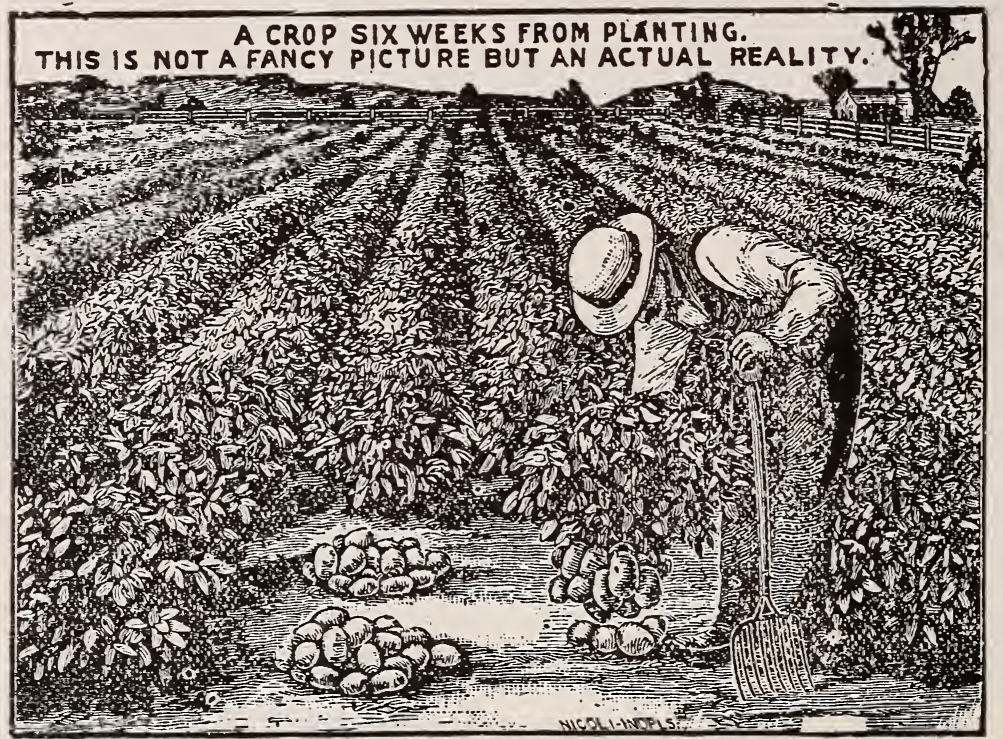

Remarkable

Earliest

Potato in existence.

No other as Early.

Valuable for Gardeners and Truckers

Bushel, $\$ 1.50$ Barrel, $\quad 3.50$
Extra Early ohio Standard extra early Potato, maturing two weeks ahead of early Rose. A special farorite with marketmen and the most profitable sort they can grow: It gives satisfaction in all parts of the country. The tubers are much smoother and of better shape than the Early Ohio. They are smooth, free from scab, and grow compactly in the hill, are easily dug; very few small ones, almost erers one being of marketable size. Peck 40c, bu $\$ 1.25$, bbl. $\$ 3.00$.
Bliss Early Triumph. Has all the good qualities of the Early Rose, is much more productive, and matures its crop at least a week in advance of the Early Rose. Tubers are of medium size, round and unismall ones: eves slightly depressed: color a beautiful light red. One of the best extra early market varieties for the South, as they are not reliable for the North. Peck 65c, bu. $\$ 1.65$, bbl. $\$ 3.75$.

A New Early Potato-Early Acme will prove itself a great favorite-more so than the Early Ohio and Early Six Weeks-both of which it resembles very much, but if anything, it is a little earlier, besides having the advantage of being newer blood. It originated from a seed ball of Sn of a ke growing between Early Ohio and Early Rose. It grows strong, upright vines, tubers compact in the hull like the Ohios, flesh very white, and of high quality Peck 50c, bu. $\$ 1.50$. barrel $\$ 3.50$

POTATO DIGGER.

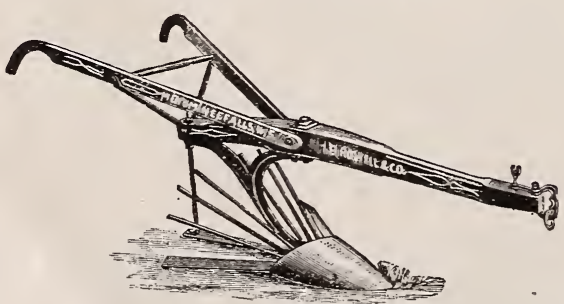

Clipper (85 lbs). Price only.
WING SHOVEL PLOW.

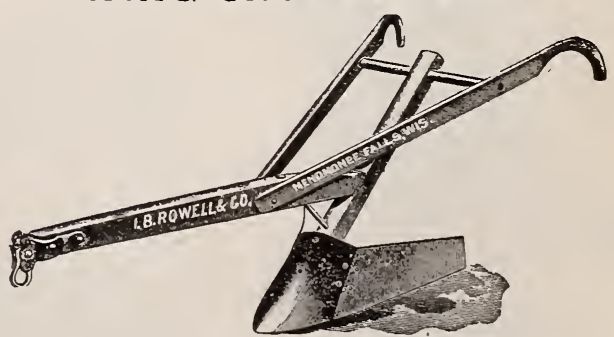

Wings are hinged and adjustable in $\pi \cdot$ idth

Price, "Rowell" (65) lbs...... 


\section{VEGETABLE SEEDS.}

We include in our list of Vegetable Seeds those of special merit. We trust this price list will be helpful to those who require seeds for fall planting, or to those who do not receive our regular Seed Annual early enough. Our Southern friends will, no doubt, find use for it. For full descriptions of any of the varieties send for our Seed Annual. Prices on Vegetables Seeds include postage. If sent by express, purchaser pasing the charges, the postage may be deducted at the rate of $8 \mathrm{c}$ per pound or pint, and 15c per quart.

\section{Beaus. B̉ohnen. UWARF WAX.} Currie's Rust Proof Golden Wax.......... Pkg. Pt. Qt.

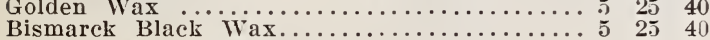

Black Wax or Butter.

White Wax

Flageolet Red Wax.

White Kidney Wax

Yosemite Mammoth iV

\section{DWARF GREEN.}

Best of All.......... Six

Long Yellow Six Weeks.

Early China Red Eye..

Extra Early Refugee...

Early Mohawk

Emperor William

Canada Wonder

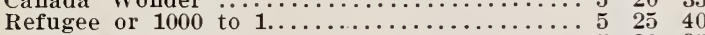

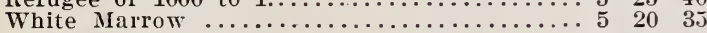

Dwarf Cranberry ..........................

\section{BUSH LIMA.}

Burpee's Bush Lima................... 5 3045 Henderson's Bush Lima.................. 5 3045

\section{POLE LIMA.}

Extra Early

King of the Garden.................. $5{ }^{3} 30 \quad 45$

Small White or, Sieva................ 530 45

POLE WAX.

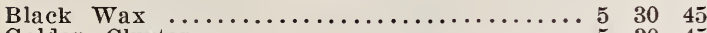

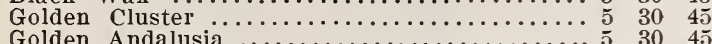

POLE GREEN.

Horticultural

Dutch Caselnnive

Lazy Wife ......

Kentucky Wonder

\section{Broccoli. Epargeltohl.}

Purple Cape

$\mathrm{Pkg} . \mathrm{Oz} .1 / 4 \mathrm{~b} .1 \mathrm{lb}$.

\section{Beets. Rothe Yucben.}

Extra Early Egyptian.............. $3 \quad 10$

Extra Early Eclipse................ 310

Edmond's Blood Turnip................... 10

Dewing's Improved Early............ 310

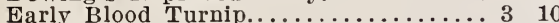

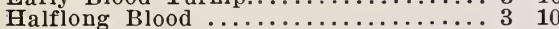

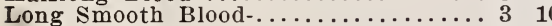

Swiss Chard

\section{Cabbage. Sirant.}

Wernich's Earliest of All.........5 15

Early Jersey Wakefield............. 5 20

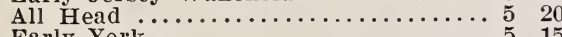

Early York ................. 5

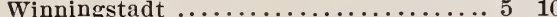

Early Flat Dutch............... 5 20

Brunswick ................. 5

Early Summer ................ 5 20

Surehead

Wernich's Holland

All Seasons

Large Late Drumhead.

Premium Flat Dutch.

Wernich's Luxemburg

Early Red Erfurt. .

Early Red Dutch.

Mammoth Red Rock.

American Dlumbead Savos.

Early Dwarf Ulm Savoy
$50 \quad 190$

$60 \quad 2 \quad 0$

$\begin{array}{llll}60 & 1 & 90 & \\ 4 & 1 & & \end{array}$

$\begin{array}{llll}40 & 1 & 50 \\ 35 & 1 & 25 & \end{array}$

$60 \quad 200$

40 1 50

$\begin{array}{lll}40 & 1 & 50 \\ 50 & 1 & 75\end{array}$

$\begin{array}{lll}50 & 1 & 7.5 \\ 60 & 2 & 00\end{array}$

$\begin{array}{llll}75 & 2 & 50\end{array}$

$\begin{array}{lll}60 & 2 & 09\end{array}$

$50 \quad 1 \quad 7.5$

$50 \quad 1 \quad 75$

$\begin{array}{lll}70 & 2 & 50\end{array}$

$50 \quad 175$

500175

$\begin{array}{llll}60 & 2 & 00 \\ 5 & 1 & 75\end{array}$

$50 \quad 1 \quad 7.5$

\section{Carrots. (ólbe Mueben.}

Early French Forcing.

Wernich's Improved Danvers.

Halflong Nantes

Improved Long Orange.

Early Scarlet Horn.

Ox Heart

Chantenay

Large White Belgian.

Mastodon

\section{Cauliflower. Blumentohl}

Henderson's Early Snowball........10 $\quad 2 \quad 25 \quad 7 \quad 00$ Wernich's Extra Early Erfurt.........10 20 2 $50 \quad 800$ Extra Early London................ $5 \quad 50 \quad 1 \quad 75 \quad 6 \%$ Autumn Giant .................. $55050 \quad 175 \quad 6 \quad 75$

\section{Corn Salad. Felb= Salat.}

Broad Leaved .................... $3 \quad 10 \quad 20$

\section{Endive. (Enbievien.}

Green Curled $\cdots$

$\begin{array}{lllll}5 & 15 & 35 & 1 & 25 \\ 5 & 15 & 35 & 1 & 25\end{array}$

\section{Kahl. frausfohl.}

Half Dwarf Green Curled.......... 5 5 $10 \quad 25 \quad 90$ Tall Brown Scotch.

\section{Lettuce. Ealat.}

May King

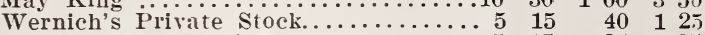

Grand Rapids Forcing................. 5 5 $15 \quad 25$

Black Seeded Simpson............... 5 5 $10 \quad 20$ 65

Early Curled Silesian................ $5 \begin{array}{llll}5 & 10 & 20 & 70\end{array}$

Silver Ball

St. Louis Butter.................... 5 5 $10 \quad 30 \quad 10$

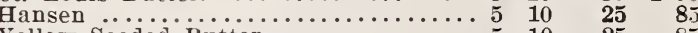

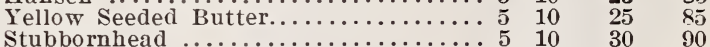

$\begin{array}{llllll}\text { New York } \ldots \ldots \ldots & 10 & 30 & 90\end{array}$

\section{Mustard. Eeni}

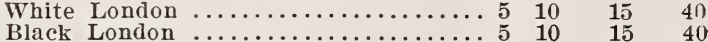

\section{Onion Sets. Eenzziviebelu.}

Write to us for prices by the bushel. One quart wi!l plant twelve feet drill; five to eight bushel per acre.

White Sets Pt. Qt.

Yellow Sets .1525

IVhite Shallots 10 Qt.

Yellow Shallot

\section{Onions. 3wiebelu.}


Peas. Crbielt.

EARLY VARIETIES. Prepaid.

Gradus

Pkg. Pt. Qt.

First and $\ddot{B}$ est

Alaska

American ironder

Little Gein

Premium Gem

Tom Thumb

Nott's Excelsior

en

Market Garden

French Can

Telephoue

Stratagem

Champion of England...

I warf White Marrow...

Large White Marrom

SUFAR FIDIBLE

$\begin{array}{lll}.05 & 25 & 40 \\ .05 & 25 & 40 \\ .05 & 25 & 40\end{array}$

$\begin{array}{lll}05 & 25 & 40 \\ 05 & 25 & 40\end{array}$

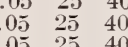

$.0525 \quad 40$

$\begin{array}{lll}05 & 25 & 40\end{array}$

$\begin{array}{llll}\text { Pt. Qt. Peck. Bu. } & \text { Pu } \\ 15 & 25 & 2 & 75 \\ 10 & 00\end{array}$

ATE CROP VARIETIES

$\begin{array}{lllllllll}05 & 25 & 40 & 15 & 25 & 1 & 25 & 4 & 00 \\ 05 & 25 & 40 & 15 & 25 & 1 & 25 & 4 & 50 \\ 05 & 25 & 40 & 15 & 25 & 1 & 25 & 4 & 50 \\ 05 & 25 & 40 & 15 & 25 & 1 & 40 & 5 & 50 \\ 05 & 25 & 45 & 20 & 30 & 2 & 00 & 7 & 50 \\ 05 & 25 & 40 & 15 & 25 & 1 & 20 & 4 & 25 \\ 05 & 18 & 30 & 10 & 15 & & 85 & 2 & 75 \\ 05 & 18 & 30 & 10 & 15 & & 75 & 2 & 75 \\ 05 & 18 & 30 & 10 & 15 & & 75 & 2 & 75\end{array}$

E POU VARINTIES

Mammoth Melting Sug..05 $25 \quad 40$

Tall Gray Sugar.

\section{FLOWER SEEDS FOF}

Quite a little time may be gained by sowing many of the flower seeds in the garden in the fall. The blooming time is thereby proportionately extended. One who is content simply to sow a few seeds in the spring deprives himself of a great amount of pleasure to be gained by fall sowing. They may also be sown in pots or boxes and had in bloom in the house during Winter. Such annuals as Sweet Alyssum, Mignonette, Nasturtiums or other common flowers afford much pleasure in the development and bloom during the winter months.

*Ageratum.-Little Dorrit, white............... Per Packet. Tom Thumb, dwarf blue

*Alssum.-Little Gem, white. . Saxatile, yellow

* Aquilegia.-(Columbine), mixed

Balsam.-(Lady's Slipper), mixed

* Bellis.-(Daisy), double mixed.

Begonia Rex.-Choice mixed.

Calceolaria.-Spotted and self-colored

* Calencuia.-Mixed

* Candytuft.-Mixed

*Carnation.-Double Red Grenadin. Wernich's Double Perfection. Fine Double, mixed. Marguerite, mixed

* Centaurea.-Cyanus

* Chrysantheminm.-Annuals, mixed Chinese, mixed

Cineraria.-Double, large flowering.

Cyclamen.-Persicum Giganteum. .

* Diantlus.-China Pink, mixed.

*Digitalis.-(Foxglove), mixed

*Gaillardia.-Mixed

*Forget-ne-not - (Iyosotis), Alpestris, white...

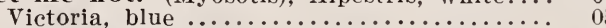

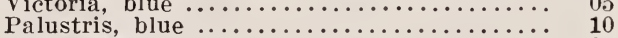

Heliotrope.-Mixed

* Hollyhock.-Mixed

*Larkspur.-Double, tall, mixed...

* Lore in a Mist.-(Wigella), Damascena.

* Mignonette.-Reseda Odorata Machet

Mimulus.-(Monkey Fiower), Moschatus

*Pansy.-Prize, Emperor William, blue.

Prize, Faust, black...............

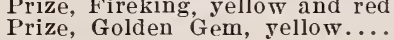

Adonis.-Rose and carmine, small flowers.

Blanche Burpee.-Eckford's largest pure white.

Blanche Ferry.-The popular pink and white.

Blushing Beauty.-Very fine, delicate pink, hooded form.

Boreatton.-Very dark maroon, self-colored Butterfly.- White, laced with lavender, notched stand-

Celestial.-Delicate azure blue, a German novelty.

Coquette-Primrose yellow, shaded with pale lavender.

Countess of Radnor.-Pale mauve or lavender.

Wernich's Boquet Mixture.-A popular mixture th at has won for us the unstinted praise of our customers. Mixed with care and consideration to produce tone and effect..Pkt. 5c, oz. 15c, 1/4 lb.

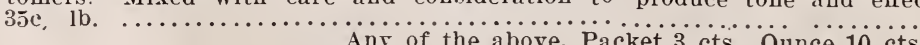

Not Prepaid.
Pt. Qt. Peck. Bu.

$\begin{array}{llllll}15 & 25 & 1 & 00 & 3 & 50 \\ 15 & 25 & 1 & 00 & 3 & 50\end{array}$

$\begin{array}{llllll}15 & 25 & 1 & 70 & 6 & 50\end{array}$

$\begin{array}{llllll}15 & 25 & 1 & 50 & 5 & 75 \\ 15 & 25 & 1 & 50 & 5 & 75\end{array}$

$\begin{array}{llllll}15 & 25 & 1 & 50 & 5 & 7.5 \\ 15 & 25 & 1 & 30 & 5 & 00\end{array}$

$\begin{array}{llllll}15 & 2.5 & 1 & 30 & 5 & 00 \\ 15 & 25 & 1 & 80 & 7 & 00\end{array}$

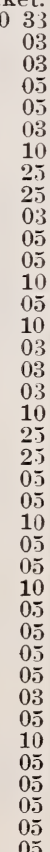

SWEET

\section{Radish. Mettig.}

Pkg. Oz. lb. $1 \mathrm{~b}$

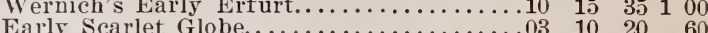

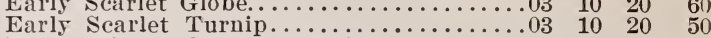

White Tipped Scarlet Turnip.............

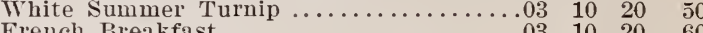

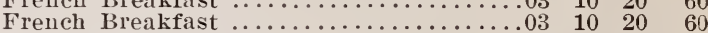

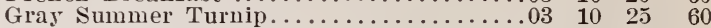

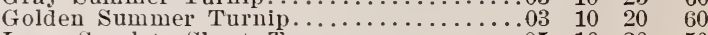

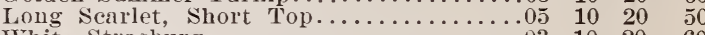

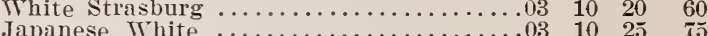

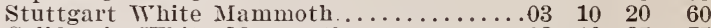

California White Mammoth......................... 10 25

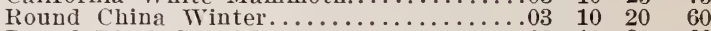

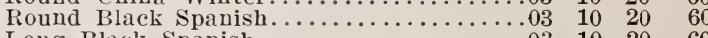

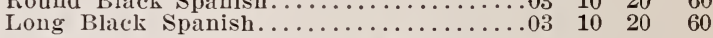

\section{Spinach. Epinat.}

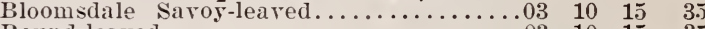

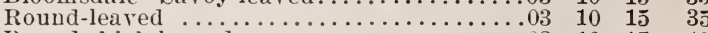

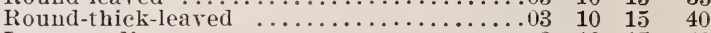

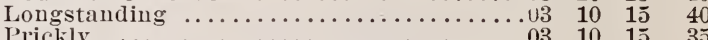

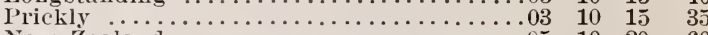

\section{FALL PLANTING.}

Such varieties as Antirrhinum, Double Daisy, CaruaCold Frame Protection in cold climates; while others, such as Asparagus, Begonia, Cineraria, Coleus, Crclamen, Ferns, Fuchsia, Petunia, Smilax, etc., should be sorvn in house or greenhouse. Aquilegia, Alyssum, Candytuft, Calliopsis, Pansy, Hardy Phlox, Poppies, Sweet Peas, Sweet William, etc., may be sown in open ground in the Autumn and they. will make their appearance early in the Spring.

Per Packet.

*Pansy.-Prize, Peacock, maroon and blue.......\$0 05

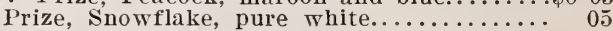

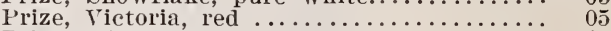

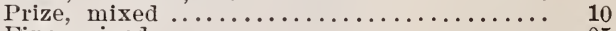

Fine, mixed ......................

Trimardeau, azure blue .............. 10

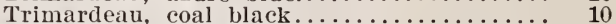

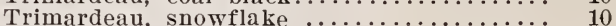

Trimardeau, striped $\ldots \ldots \ldots \ldots \ldots \ldots \ldots \ldots \ldots \ldots \ldots \ldots$

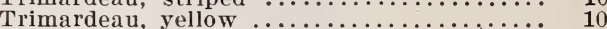

Trimardeau, mixed $\ldots \ldots \ldots \ldots \ldots \ldots \ldots \ldots \ldots . \ldots \ldots$

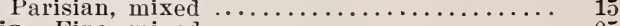

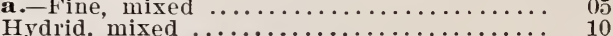

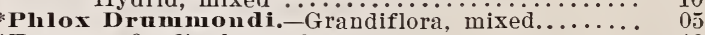

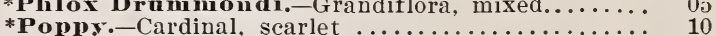

Peacock, crimson ...................... 10

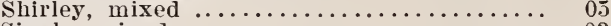

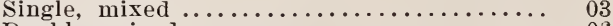

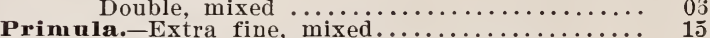

Stocks.-Large, flowering 10 weeks, crimson........... 10

Large, flowering 10 weeks, carmine ....... 10

Large, flowering 10 weeks, canary ....... 19

Large, flowering 10 weeks, pure white...... 10

Large, flowering 10 weeks, rose .......... 10

Large, flowering 10 weeks, mixed $\ldots \ldots \ldots \ldots$.

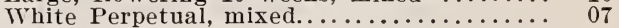

Giant, Perfection, mixed................... 10

Dwarf. German, 10 weeks, mixed......... 05

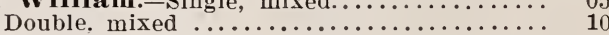

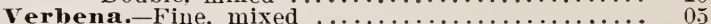

Hybrida, mixed . .............................. 10

violet. - Blue, sweet $\ldots \ldots \ldots \ldots \ldots \ldots$

White sweet

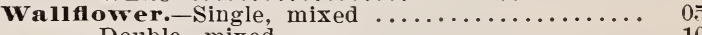

Double, mixed ................... 10

PEAS.

Crown Princess of Prussia.-Flesh-colored and salmon-buff.

Emily Eckford.-Reddish mave, fading to light blue, superb flower.

Firefly.-Intense glowing scarlet, wings fiery scarlet.

Indigo King.-Maroon, nearly indigo.

Invincible Searlet.-Bright scarlet.

Lottie Eckford.- Thite, suffused with lavender blue.

Lovely.-Soft shell pink. Truly most "lovely."

Iaid of Honor.- White, edged violet.

Mrs. Gladstone.-A lovely soft pink.
Princess Beatrice.-A ponular rosy pink.

Princess Beatrice.-A ponular rosy pink. 


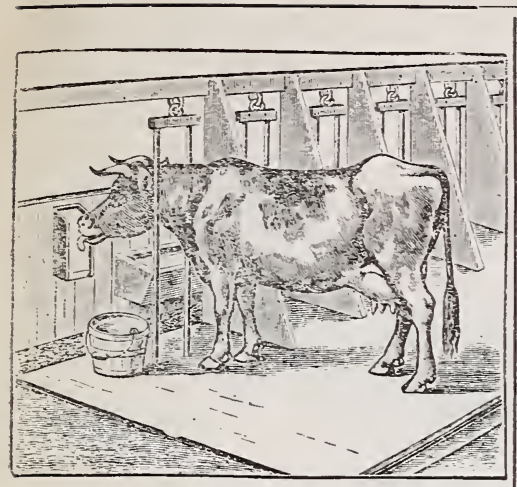

SALT BRICKS

FOR

\section{Horses and Stock}

PURE SALT

ALWAYS AT THEIR

TONGUES END.
This method of feeding pure salt to horses and stock has been adopted in the largest stables and is growing in favor daily. It enables the animals to gratify their desire for salt whenere their systems require it. They are not required to take impurities with it as is the case with rock salt. And if you mix fine salt with their feed they have to swallow the salt, whether too much or too little. Horse owners be clean oats and hay and pure water. IVe urge them to consider also the adrisability of proriding them with pure salt in this form, enabling them to take it as ther need it. The Galvanized Iron Feeder, as shown ill cut, i so simple in construction that there is nothing about it to get out of order.

The Feeders are loaned, not sold, but a deposit of 25 cents is required for each Feeder. If at ans time it is desired to discontinue the use of the Salt Bricks we will remit the full amount of said deposit upon the return to us of the Feeders.

The Bricks and Feeders are packed separate. one dozen in a case.

Price of Bricks. Each 25 cts.; per dozen \$2.00: J dozen $\$ 9.00: 10$ dozen $\$ 17.50$
Price of Feeders. Each 25 cents.

\section{Beckoe Stock Food.}

IT DOES WHAT OIL MEAL DOES; IT DOES WHAT OIL MEAL DOESN'T; AND IT DOES IT AT ABOUT $1-4$ THE COST IF YOU FEED IT REGULARLY TO YOUR HORSES, CATTLE, SHEEP AND SWINE.

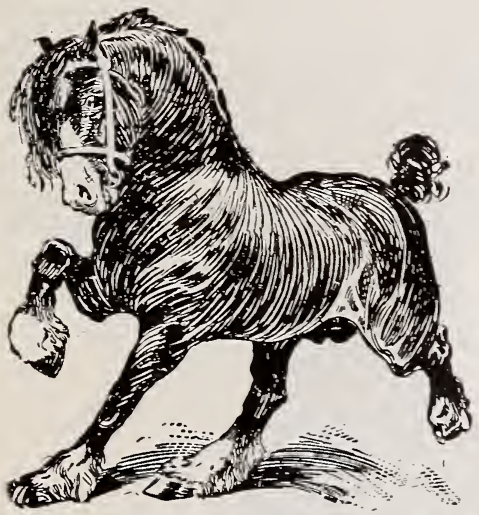

lou will save big money on sour feed bills.
liou will seldom hare a sick animal on your hands.

Your stock will put on the greatest amount of Hesh in the imumi of cost. Four stock will always have smooth, glossy coats.

Your stock will get the last atom of nutriment from the grain given them, because Beckoe produces perfect assimilation, and there is little of that 40 PER CENT WAS'IE shown by all scale tests where Beckoe Stock Food is not used.

You will get the "condimental food sensation" of the new centurs; a food which is about fire

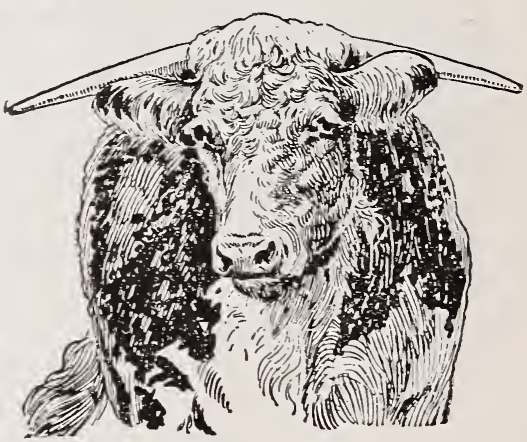

times as strong as any other preparation on the market, but one teaspoonful being used to each feed for for: not a lot of valueless filler, or worthless but expensive books con taining hundreds of more or less significant testimonials from men who got special prices which YOU do not get.

PRICE 5 LB. WOODEN BOX \$1.00 (ORIGINAL PACKAGE.)

\section{BARWELL'S STOCK FOODS.}

\section{ANIMAL REGULATOR.}

A most valuable Tonic, Blood Purifier and Regulator for the common ailments of Cattle, Horses, Sheep and Hogs. All of the ingredients of which it is composed are plainly given and its value will be apparent to every intelligent stock owner. It is carefully manufactured from an old English formula that has been in use with the greatest success for 25 vears on the farms and in the stables of many of the largest landed proprietors of that country. It is compounded of the best quality of materials only, and attention is respectfully called to the fact that positively no ingredients whatever are used in its manufacture except the following: Perurian Bark, Foenugreek and Gentian for a tonic, and as a stimulant, Sulphates of Iron and Soda and Chloride of Sodium for kidney troubles and constipation: Anise, Powdered Ginger and Licorice-excellent cordials and invigorants; Pure Locust Bean Meal and Blatchford's Calf Meal-nutritious and develoning: Powdered Sarsanarilla, Charcoal and Sulphur and Pure Crushed Flax Seed-a diuretic alterative and purifier. Trial package (21\% lhs.) he mail, postpaid. 65c. Per 50 lb. bag, \$3.50; $100 \mathrm{lbs}$. $\$ 6.00$.

\section{SUGAR AND FLAX SEED.}

Composed entirely of the three great elements necessary for profitable and healthy feeding, viz.: Oil, Sugar and Protein combined in the correct proportions and most digestible form. The whole toned by the addition of those best known and well recognized Horse and Cattle tonics, Pure Gentian, Foenugreek and Anise with Salt, which lent effect upon the appetite, digestion and condition of all domestic animals.

Being rery Sweet and Oily, it is eaten with the great est relish by all sick and ailing animals when they refuse all other food, and it has immediate beneficial result. on their condition. Per $50 \mathrm{lbs} ., \$ 2.00 ; 100 \mathrm{lbs}$., $\$ 3.50$.

\section{CALF MEAL.}

The perfect milk substitute for raising calres. $100 \mathrm{lbs}$ of it makes 100 gallons of Rich Nutritious Gruel

Calves can be raised upon it alone without milk after they are a few dars old. It is manufactured to resemble new milk as nearly as possible in chemical composition, hence its great success. Per 50 lbs. $\$ 2.00 ; 100$ lbs. $\$ 3.50$ 


\section{Little Giant Thresher "Pennsylvania" No. 3.}

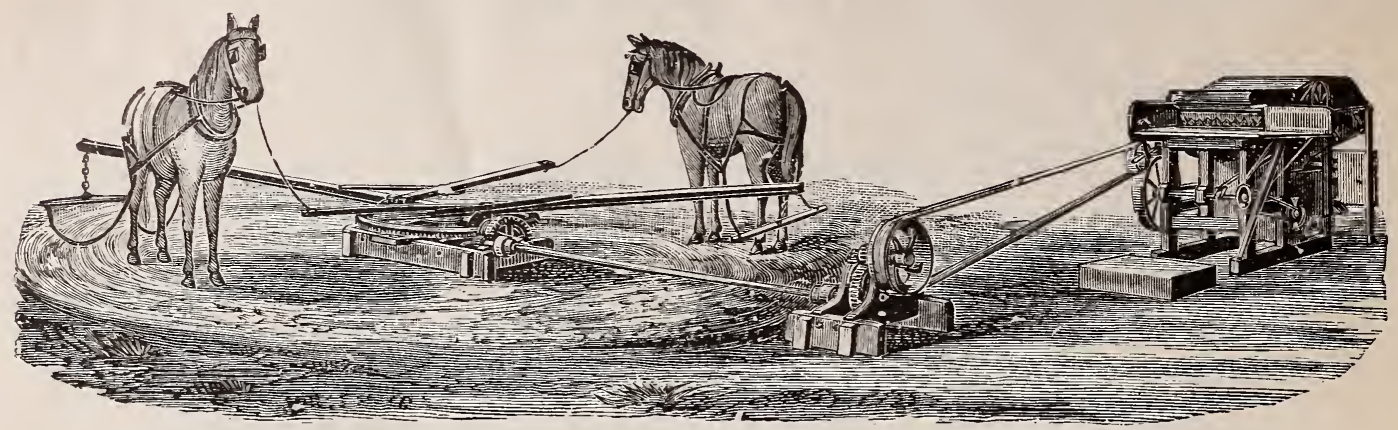

It will thresh and clean from 75 to 125 bushels of wheat per day. When not wanted in use the little machine can be easily and quickly taken apart and stored in small space.

One-horse Direct Geared Lerel-tread Power, with speed Regulator, Trestle and Bridge, with No. 3 Pennsylrania Thresher and Cleaner, Wrenches, Belts, Oiler, Dogs, etc., complete for threshing and cleaning grain Weight, $2145 \mathrm{lbs}) \ldots \ldots \ldots \ldots \ldots \ldots \ldots \ldots \ldots \ldots 185 \ldots \ldots$ If 4 Wheel Truck for Tread Power is wanted, add 35.00

Hare had full satisfaction with our 1-horse level-tread porer and our No. 3 Pennsslvania thresher. Have run the machine two seasons. One day we threshed 248 bushels of wheat, and have gone over 200 bushels several times, and threshed 186 bushels of oats in four hours, and can thresh 500 bushels of oats in one day with ease. We use mules weighing 1000 pounds each, and have one weighing 1200 pounds. We are doing nearly as much work as some can do with a two-horse outfit.

\section{CARTER H. RICE.}

New Market, Madison Co., Ala.
(Jan. '99.) rears and it is doing as good work as at the beginning. We can thresh from 300 to 500 bushels per day, using four horses on our lever power. Last season I put six horses in the power and threshed 63 bushels of oats in one hour, just to convince a "doubting Thomas" that the machine would even do more than I claim for it. The machine has been entirely satisfactory.

(July'97.) Leber, Pierce Co, Wash.
Pennsylrania Thresher No. 3..(Weight 1050 lbs.) $\$ 105.00$ Four-horse Climax Power, Tumbling Rods and Couplings ................ (Weight 1100 lbs.) $\quad 39.0$ Iron Frame Berel Gear Jack...(Weight $100 \mathrm{lbs}$.) $\quad 9.75$ 40 feet Rubber Belting, 31/2 inch, 3-ply.......... 5.60

$\$ 158.35$

I promised to send rou a report of the doings of my Two-Horse Lerel-Tread Power and the little Giant, No 2 , and beg to submit the same. We threshed wheat and oats for the 12th bushel, the other grains at 5 and 6 cents per bushel, and the books show the following:

Threshed $4,6481 / 2$ bushels wheat-1-12th at $70 \mathrm{c} \ldots \$ 271.13$ Threshed 5,764 bushels oats-1-12th at 35c.... 168.12 Threshed 1,692 bushels Kaffir corn at $5 \mathrm{c} \ldots \ldots . . .68 .60$ Threshed 1,255 bushels Sorgum seed at 5c..... 62.75 Threshed 137 bushels rye $\ldots \ldots \ldots \ldots \ldots \ldots \ldots, 42.24$

Total, 14,2501/2

*Figures not given.

$\$ 631.84$

The wheat crop was vers light here last season, mak ing only 8 to 10 bushels per acre. The machine has done far better than you recommended, and our people say it is the best grain saver they ever saw.

(Jan. '99) J. F. BOLANDER,

\section{Heebner's Two=Horse Power Threshing Outfit.}

The illustration shows our Two-Horse Direct Geared Level-Tread Power with No. 2 Little Giant Thresher and Cleaner. When sold in the West or Northwest the machine is generally ordered full rigged.

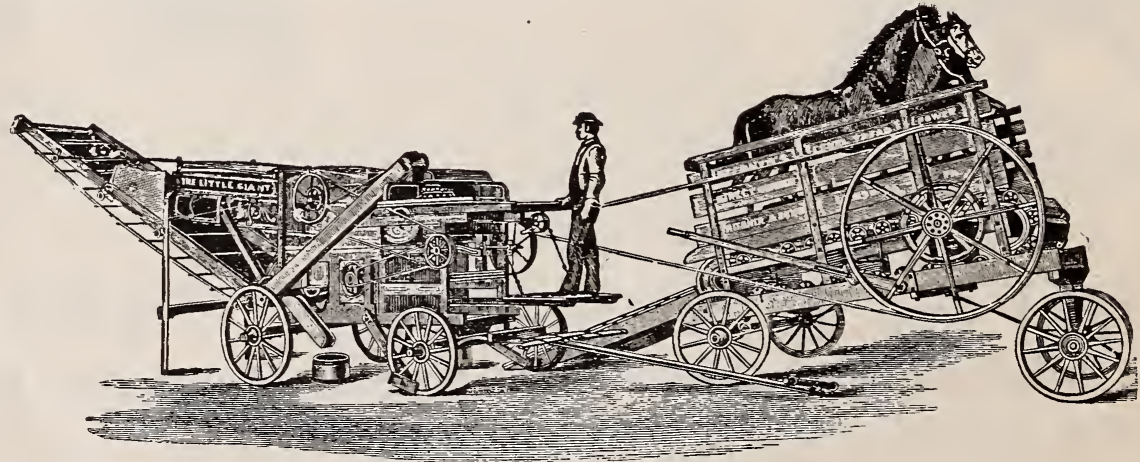

This machine has a capacity of from 200 to 500 bushels per day, the quantity being determined by the weight of the team, the length of the s:raw, the condition the straw is in (whether dry or damp), the yield of grain per acre, etc. Our estimates as to the capacity of this thresher is based on wheat.

\section{Price With Tread Power.}

Two-Horse Direct Geared Lerel-Tread Power with Speed Regulator, Trestle and Bridge, with No. 2 Little Giant Thresher and Cleaner, Wrenches, Belts, Oiler, Dogs, etc., complete for threshing and cleaning grain. (Weight $3300 \mathrm{lbs}$.) $\$ 280.00$ The same mounted on wheels.. (Weight $4600 \mathrm{lbs}$ ) 360.00 The same also with Mountings, Tailings Elevator, 14 foot Straw Stacker and Elevating Jack,

(Weight $4800 \mathrm{lbs}$ ).................... 405.00

\section{Price With Sweep Power.}

No. 2 Little Giant Thresher and Cleaner (Weight

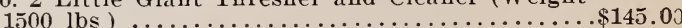
Four-Horse Climax Power, Tumbling Rods and Couplings .................. (Weight 1100 lbs.) 39.00 Iron Frame Berel Gear Jack..(Weight 100 lbs.), 9.75 50 feet Rubber Belting, 4 inch. 4 ply............ 8.00 If Trucks are wanted for Thresher (Weight 650 . 35.03 If Tailing Elerator is wanted... (Weight $200 \mathrm{lbs}$ ), 12.25 If 14 foot straw stacker is wanted, add........... 20.00 
CLIPPER CLEANER.

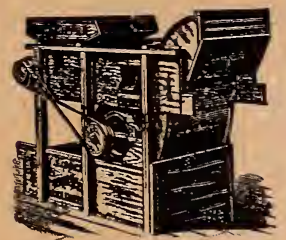

This machine cleans all kinds of seeds and grain to the highest possible grade. It has the best of zinc sieves, seren in number, requires no attachments for cleaning wheat, oats, barley, corn, beans, rice, buckwheat, flax, garden seeds.

It has spreading board, end shake, and the vertical blast, which are found in the Clipper and no other, which makes them the leading and standard cleaner of the United States and Canada. Wt. $180 \mathrm{lbs}$.

Price, No. $1 . \ldots \ldots \ldots \$ 2000$ Price, No, 2
"CREAM CITY" FANNING MILLS.

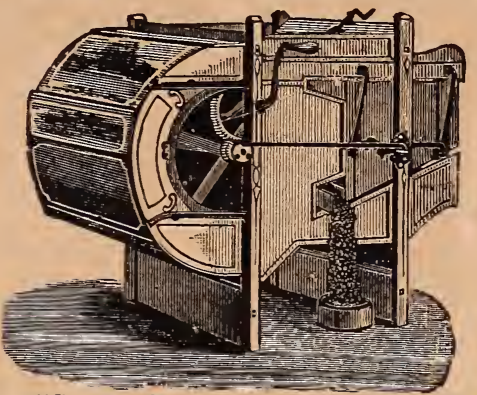

The "Cream City" is an excellent chaffer, having plenty of wind and shake. Having two shoes it carries more screens than any other Mill in the market. It will separate oats and all small seeds, such as pigeon grass, buckwheat, cockle, cheat, and other wild, wild from wheat at one operation. And the good from wheat at one operation. And the good and large seed can be separated from the small and the poor. It is a perrect cleaner of both clover and timothy. With each Mill we fur grader, 1 barley sieve, 1 oat sieve, 1 rye sieve, 1 flax sieve, 1 clover sieve and 1 timothy sieve, Shipped knocked down unless otherwise ordered.

Price, No. 1 Mill, Sieves 24 in., Weight 150 lbs. ..................... $\$ 1350$ Price, No. 2 Mill, Sieves 30 in., Weight
EXCELSIOR MILL

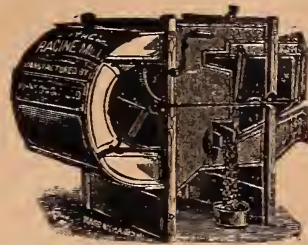

The regular outfit, known as "Commercial," will be sent with each mill, unless otherwise specified, and is as follows:

1 wheat hurdle or gang with zinc sieve on top; wheat screen; 1 wheat grader: 1 oat sieve; 1 barley sieve 1 timothy sieve and 1 clover sieve.

Price, No. 1 Mill, Sieves,

24 in., wt. 140 lbs....\$10 90

Price, No. 2 Mill, Sieves,

30 in., wt. 155 lbs.... 1500

\section{Excelsior Junior.}

Similar to the foregoing. only gearing is on the out side.

Price only ...........\$9 25 Clover and Timoth extra, each .........45 cts.

\section{Excelsior Wine and Cider Mills.}

Made in Three Sizes, Junior, Medium and Senior.

These Mills are well known and justly celebrated for their superior excellence. They are well made, strong, run light and are highly finished. Each Mill is furnished with 2 tubs, 2 strainers, and 1 follower block.

Junior-Capacity 1 to 2 barrels cider per day, weight $150 \mathrm{lbs}$., price...... $\$ 1300$

Medium-Capacity 1 to 3 barrels of cider per day, weight $250 \mathrm{lbs}$, price.....\$1690

Senior-Capacity 4 to 6 barrels cider per day, weight 360 lbs., price.......\$21.80

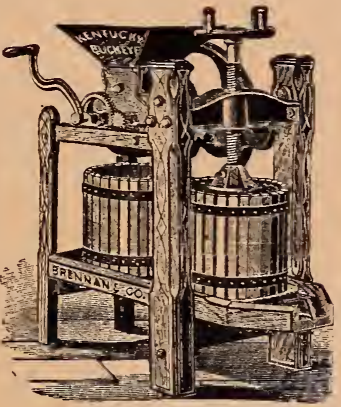

\section{THE LOWELL SPRAYER.}

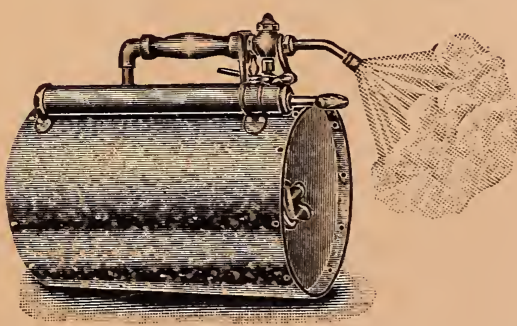

A cumpressed air sprayer. Works very easy and rapid. The action of the air keeps the solution thoroughly stirred. It has a funnel shaped head, making it handy for filling. The amount of spray is easily governed by simply filling. The amount of spray is easily governed by simply pressing the thumb valre with a quick or slow motion. spray crook as desired. One filling will spray 400 hills of potatoes. With the 4-foot hose attachment you can easily spray into the tops of the highest fruit trees. It is thoroughly riveted and will stand a pressure of 50 poinds. All working parts made of brass. Fully guarpo:inds. All working parts made

anteed. Weight packed, $12 \mathrm{lbs}$. Brass Tank, $\$ 5.50$. With fruit tree attachment.. 600 Will send either prepaid east of the Mississippi for 50 sents extra.

\section{Cummings Cutter No. I.}

This cutter is a band machine only and $\underset{\text { has three } 83 / 4}{\text { in. knives. It has }}$ the upward cut and the rocking feed roller, and the power is applied knife shaft without any intermediate gearing. Length of cut $\% / 8$ and $7 / 8$ in. Capacity, $400^{8} \mathrm{lbs}$ per hour.

Weight, $200 \mathrm{lbs}$

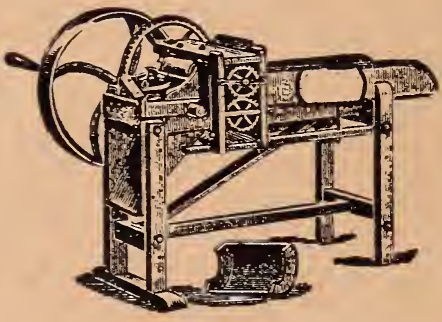

\section{Cummings Cutter No. 2.}

Tuis is the largest hand machine, and is not recom. mended if much cutting is to be done, as it requires lots of muscle, which makes it hard work. If you do not have power, but plenty of strong boys, this machine answers nicely. Length of cut $3 / 8$ and $7 / 8$ in. 4 knives, 10 in. long. Capacity, from 400 to $800 \mathrm{lbs}$. per rour.

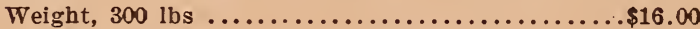

\section{Cummings Cutter No. $21 / 2$.}

This cutter has four 10-in knives, is intended for power, but can be run by hand. Length of cut, $\$ / 8$ and $7 / 8$ in. Power required, two horse. Capacity about 2,000 lbs. per hour of dry feed. Speed, 400 to 600 revo. lutions per minute.

Weight, 300 lbs............................ 75

Crusher Attachment. Weight, $180 \mathrm{lbs}$. Extra.... 1095 Shredder Attachment. Weight, 150 lbs. Extra... 1350

Improved Cummings Cutter No. 3 .

The No. 3 cutter is intended for power only. It is made on the same lines as our smaller machines, being larger, heavier, and having capacity great enough to feed forty to sixty head of stock. Equipped with three 12-in. knives; cuts four lengths-1/4 1/2, s/4 and three 12 -in. knives; cuts four lengths $-1 / 4,1 / 2,3 / 4$ and 400 to 600 revolutions; power required, two-horse; capacity, 3,000 lbs. dry feed per hour.

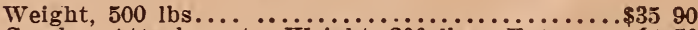
Crusher Attachment. "Weight, 200 ibs. Extra..... 14 50 Shredder Attachment. Weight, 200 lbs. Extra.. 1900 12 Foot Carrier. Weight, 300 lbs. Extra....... 1515

(If longer Carrier is wanted add 95c per foot.) 


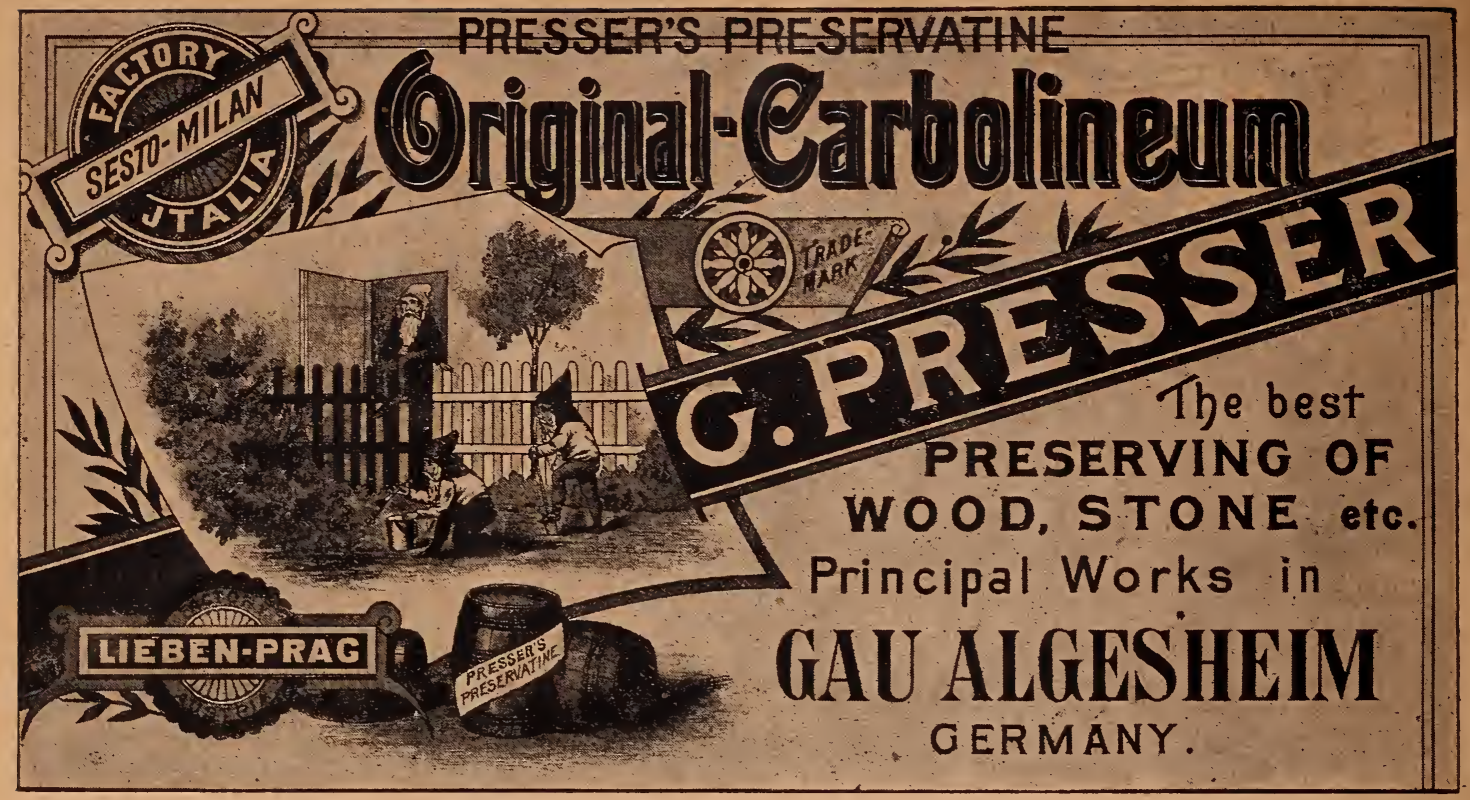

A Wood Preserving and Impregnant Paint Without Equal.

BEWARE OF IMITATIONS.

Uriginal Carbolineum has been in use for over twenty years and has given the best of satisfaction. It is better and cheaper than Linseed Oil Paint. It only comes in Liquid form, remains a Liquid for jears, is alwass ready for use and does not evaporate and become dry like other paints.

'This is the only gennine article on the market. It is manufactured by Geo. Presser, Chemist in Gau Algesheim, Germany, with branch factories in Lieben Prag, Austria, and Sesto-Milan, Italy.

\section{Carbolineum-Its Usefullness:}

\section{As an Impregnating Paint.}

$T$ is an excellent antiseptical impregnant and covering and the best known product for the preservation of ject to dampness, dry and from becoming mouldy.

COR preserving all kinds of woodwork it has no equal. F It is an antiseptic oil stain of a nut brown color which will deeply penetrate wood when applied with
a brush or sprayer. Its covering capacity makes it the cheapest and best paint for all farm buildings, such as barns, granaries, stables, silos, fences, etc.

CENCE-POSTS, floors, sidewalks, in fact all woodwork, - whether below or above ground, will never rot or 1 break down if coated with Original Carbolineum. Shingled roofs will never leak nor shingles rot or warp if painted with it. Troughs, tanks, cisterns and cellars will always be clean and fresh if given a coat of Original Carbolineum.

\section{DIRECTIONS FOR USING.}

To gain best results, Original Carbolineum should be slightly warmed if applied in cold weather. In summer never apply during hottest time of the day. Apply with brush or sprayer.

\section{COVERING CAPACITY.}

One Gallon will cover 300 square feet dressed lumber, 1 coat. One Gallon will cover 250 square feet rough lumber, 1 coat. One Gallon will cover 100 square feet shingle roof, 1 coat.

If a second coat is necessary, only one-quarter the quantity additional. All underground work should have two coats and care should be taken that the ends of the wood is well saturated.

\section{PRICES.}

5 Gallons, weight 50 lbs............... 4.50 Prepaid by freight to all Railway Stations in 10 Gallons. Weight 100 lbs................. 8.50$\}$ Wisconsin, Iowa, Minnesota, Michigan, Nebras25 Gallons, Weight 250 llos...................

50 Gallons, Weight 500 lbs...................35.00

If purchaser wishes to pay freight, 5 cents per gallon can be deducted from above prices.

Per Qt., 35 cts.; 1/2 Gallon, 65 cts.; 1 Gallon, \$1.00, Not Prepaid. 